Article

\title{
Synthesis of HZSM-5 Rich in Paired Al and Its Catalytic Performance for Propane Aromatization
}

\author{
Dezhi Shi ${ }^{1,2,+}$, Sen Wang ${ }^{1,2,+} \mathbb{D}$, Hao Wang ${ }^{1, *}$, Pengfei Wang ${ }^{1}$, Li Zhang ${ }^{1,2}$, Zhangfeng Qin ${ }^{1} \mathbb{D}$, \\ Jianguo Wang ${ }^{1}$, Huaqing Zhu ${ }^{1, *}$ and Weibin Fan ${ }^{1, *}$ \\ 1 State Key Laboratory of Coal Conversion, Institute of Coal Chemistry, Chinese Academy of Sciences, \\ 27 South Taoyuan Road, Taiyuan 030001, Shanxi, China; shidezhi@sxicc.ac.cn (D.S.); \\ wangsen@sxicc.ac.cn (S.W.); wangpf@sxicc.ac.cn (P.W.); zhangli603@sxicc.ac.cn (L.Z.); \\ qzhf@sxicc.ac.cn (Z.Q.); jgwang@sxicc.ac.cn (J.W.) \\ 2 University of Chinese Academy of Sciences, Beijing 100049, China \\ * Correspondence: wanghao@sxicc.ac.cn (H.W.); zhuhq@sxicc.ac.cn (H.Z.); fanwb@sxicc.ac.cn (W.F.) \\ + These authors equally contributed to this work.
}

Received: 26 May 2020; Accepted: 2 June 2020; Published: 3 June 2020

check for updates

\begin{abstract}
A series of HZSM-5 catalysts with similar $\mathrm{Si} / \mathrm{Al}_{\mathrm{F}}$ mole ratio, textual properties and morphology, but different contents of $\mathrm{Al}_{\mathrm{F}}$ pairs, were synthesized by controlling the $\mathrm{Na} / \mathrm{Al}$ molar ratios in the precursor gel and used for propane aromatization. It is shown that the catalyst with a $\mathrm{Na} / \mathrm{Al}$ molar ratio of 0.8 in the synthetic gel possesses the highest paired $\mathrm{Al}_{\mathrm{F}}$ concentration $(64.4 \%)$ and shows higher propane conversion (38.2\%) and aromatics selectivity (19.7 wt.\%). Propane pulse experiments, micro reactor activity estimation, Operando diffuse reflectance ultraviolet-visible (DR UV-vis) spectroscopy and Fourier Transform Infrared Spectroscopy (FTIR) analysis of coke species deposited on the catalysts provide evidence that $\mathrm{Al}_{\mathrm{F}}$ pairs in the ZSM- 5 framework promote oligomerization and cyclization reactions of olefins, and then produce more aromatics. Density Functional Theory (DFT) calculations demonstrate that the cyclization of olefins and hydride transfer reaction occurring on $\mathrm{Al}_{\mathrm{F}}$ pairs in $\mathrm{HZSM}-5$ zeolite show a lower free energy barrier and a higher rate constant than those on single $\mathrm{Al}_{\mathrm{F}}$, indicating that the structure of $\mathrm{Al}_{\mathrm{F}}$ pairs in the $\mathrm{HZSM}-5$ zeolite has a stronger electrostatic stabilization effect on the transition states than that of single $\mathrm{Al}_{\mathrm{F}}$.
\end{abstract}

Keywords: HZSM-5; Al pairs; propane aromatization; Operando DR UV-vis; DFT calculations

\section{Introduction}

The aromatization of light alkanes (mainly propane and butane) has been extensively studied for almost three decades due to its importance in the economic and strategic fields [1,2]. For the propane aromatization process, Zn, Pt and Ga-promoted ZSM-5 catalysts are recognized as effective bifunctional catalysts [3-15]. Light alkane chain growth on bifunctional catalysts involves dehydrogenation, oligomerization, cyclization, and aromatization steps, which proceed in parallel with acid-catalyzed and thermal cracking reactions. In general, metal ( $\mathrm{Zn}, \mathrm{Pt}$ and $\mathrm{Ga})$ species are responsible for dehydrogenation processes, while zeolitic acid sites serve catalytic functions for the oligomerization and cyclization steps [3,12,13]. ZSM-5 zeolite has been proved to be the most promising component of aromatization catalysts because of its high hydrothermal stability, unique shape-selective behavior, adjustable acidity and suitable crystal structure [1,3]. However, few studies have examined the influence of the framework aluminum $\left(\mathrm{Al}_{\mathrm{F}}\right)$ distribution of HZSM-5 zeolites on its propane aromatization catalytic performance.

In the framework of HZSM-5, there are two types of $\mathrm{Al}$ species, i.e., paired $\mathrm{Al}$ and single $\mathrm{Al}$. The term paired $\mathrm{Al}$ refers to the $\mathrm{Al}-\mathrm{O}-(\mathrm{Si}-\mathrm{O})_{1,2}-\mathrm{Al}$ sequences, whereas isolated single $\mathrm{Al}$ atoms represent $\mathrm{Al}-\mathrm{O}-(\mathrm{Si}-\mathrm{O})_{\geq 3}-\mathrm{Al}$ sequences [16]. The content of $\mathrm{Al}_{\mathrm{F}}$ pairs and single $\mathrm{Al}_{\mathrm{F}}$ can be estimated 
by using exchanged Co(II)-ZSM-5 samples. Hexaaquocomplexes of $\mathrm{Co}^{2+}$ ions can balance the negative charges generated by two close $\mathrm{Al}$ atoms, named as $\mathrm{Al}_{\mathrm{F}}$ pairs (located in one framework ring or different framework rings), whereas the single $\mathrm{Al}$ atom is defined as one $\mathrm{Al}$ atom sitting in a five- or six-membered ring that cannot be coordinated by $\mathrm{Co}^{2+}$ ions $[17,18]$. $\mathrm{Al}_{\mathrm{F}}$ distribution can be regulated in the synthesis process of the ZSM- 5 zeolites by changing the $\mathrm{Si}$ source (such as TEOS, colloidal silica and sodium silicate), $\mathrm{Al}$ source $\left(\mathrm{AlCl}_{3}, \mathrm{Al}\left(\mathrm{NO}_{3}\right)_{3}, \mathrm{NaAlO}_{2}\right.$ and $\left.\mathrm{Al}(\mathrm{OH})_{3}\right)$, sodium content, and organic templating [17,19-21]. Biligetu et al. [19] reported that ZSM-5 zeolites with different framework $\mathrm{Al}$ achieved by adding various alcohols exhibit different methanol-to-olefins (MTO) performance, whereby a relatively large number of $\mathrm{Al}_{\mathrm{F}}$ pairs in the catalyst produces more ethene by enhancing the "aromatics-based cycle" [22]. Sazama and co-workers [20] found that $\mathrm{Al}_{\mathrm{F}}$ pairs in $\mathrm{HZSM}-5$ framework were beneficial to 1-butene oligomerization in 1-butene conversion, whereas single $\mathrm{Al}_{\mathrm{F}}$ was favorable to 1-butene cracking and gave higher selectivity to lower olefins. Song et al. [23] reported that $\mathrm{Al}_{\mathrm{F}}$ pairs cooperatively catalyze alkane cracking at higher turnover rates than on single $\mathrm{Al}_{\mathrm{F}}$ and the apparent activation entropies become less negative at higher $\mathrm{Al}_{\mathrm{F}}$ pair concentrations although the apparent activation energies are similar on HZSM- 5 catalysts with different concentrations of single $\mathrm{Al}_{\mathrm{F}}$ and $\mathrm{Al}_{\mathrm{F}}$ pairs on different alkane reactants (propane, $n$-butane, and $n$-pentane); thus, enhanced cracking rates at these $\mathrm{Al}_{\mathrm{F}}$ pairs are mainly due to more positive intrinsic activation entropies. Tabor et al. reported that turnover rates for the conversion of propene to $\mathrm{C}_{4}-\mathrm{C}_{9}$ olefins and to BTX aromatics are 5-8 times and 20 times higher, respectively, over $\mathrm{Al}_{\mathrm{F}}$ pairs than those over single $\mathrm{Al}_{\mathrm{F}}$ [24]. It is thus firmly believed that the distribution of $\mathrm{Al}_{\mathrm{F}}$ in HZSM-5 must be an important factor in catalytic activity and therefore, it is necessary to investigate the impact of $\mathrm{Al}_{\mathrm{F}}$ distribution in $\mathrm{HZSM}-5$ on propane aromatization.

In this work, a series of HZSM- 5 catalysts with different contents of $\mathrm{Al}_{\mathrm{F}}$ pairs were synthesized by controlling the $\mathrm{Na} / \mathrm{Al}$ molar ratios in the precursor gels and $\mathrm{HZSM}-5$ catalysts with similar $\mathrm{Si} / \mathrm{Al}_{\mathrm{F}}$ molar ratio, textual properties, and morphology were applied to propane aromatization reaction. It is found that the $\mathrm{Al}_{\mathrm{F}}$ pair content in $\mathrm{HZSM}-5$ has a significant influence on propane conversion and selectivity to aromatics. Operando UV-vis spectroscopy and gas chromatography-mass spectrometry (GC-MS) and theoretical calculations revealed that $\mathrm{Al}_{\mathrm{F}}$ pairs in $\mathrm{HZSM}-5$ framework promote oligomerization and cyclization reactions of olefins in propane aromatization. The structure of $\mathrm{Al}_{\mathrm{F}}$ pairs in the $\mathrm{ZSM}-5$ zeolite shows stronger electrostatic stabilization effect on the transition states than that of single $\mathrm{Al}_{\mathrm{F}}$. These results gave new insights into the impact of $\mathrm{Al}_{\mathrm{F}}$ distribution in $\mathrm{HZSM}-5$ on propane aromatization, which should facilitate the design of high performance catalysts.

\section{Results and Discussion}

\subsection{Physicochemical Properties of Catalysts}

The X-ray diffraction patterns of the catalysts are shown in Figure 1. All of the catalysts exhibit the typical reflections of a MFI zeolite-type framework with similar crystallinity. The lattice parameters of the catalysts calculated trough Rietveld refinement of the XRD data are shown in Table 1. All of the catalysts have similar cell parameters. The SEM images of the catalysts are shown in Figure 2. All of the catalysts exhibit similar morphology and small uniform particles with an average size of $\sim 100 \mathrm{~nm}$. The subtle difference in these four samples is that pictures of samples $\mathrm{HZ}(0), \mathrm{HZ}(0.4)$ and $\mathrm{HZ}(0.8)$ shows almost the same particle agglomerations while sample HZ(1.1) shows smaller particle agglomerations. 


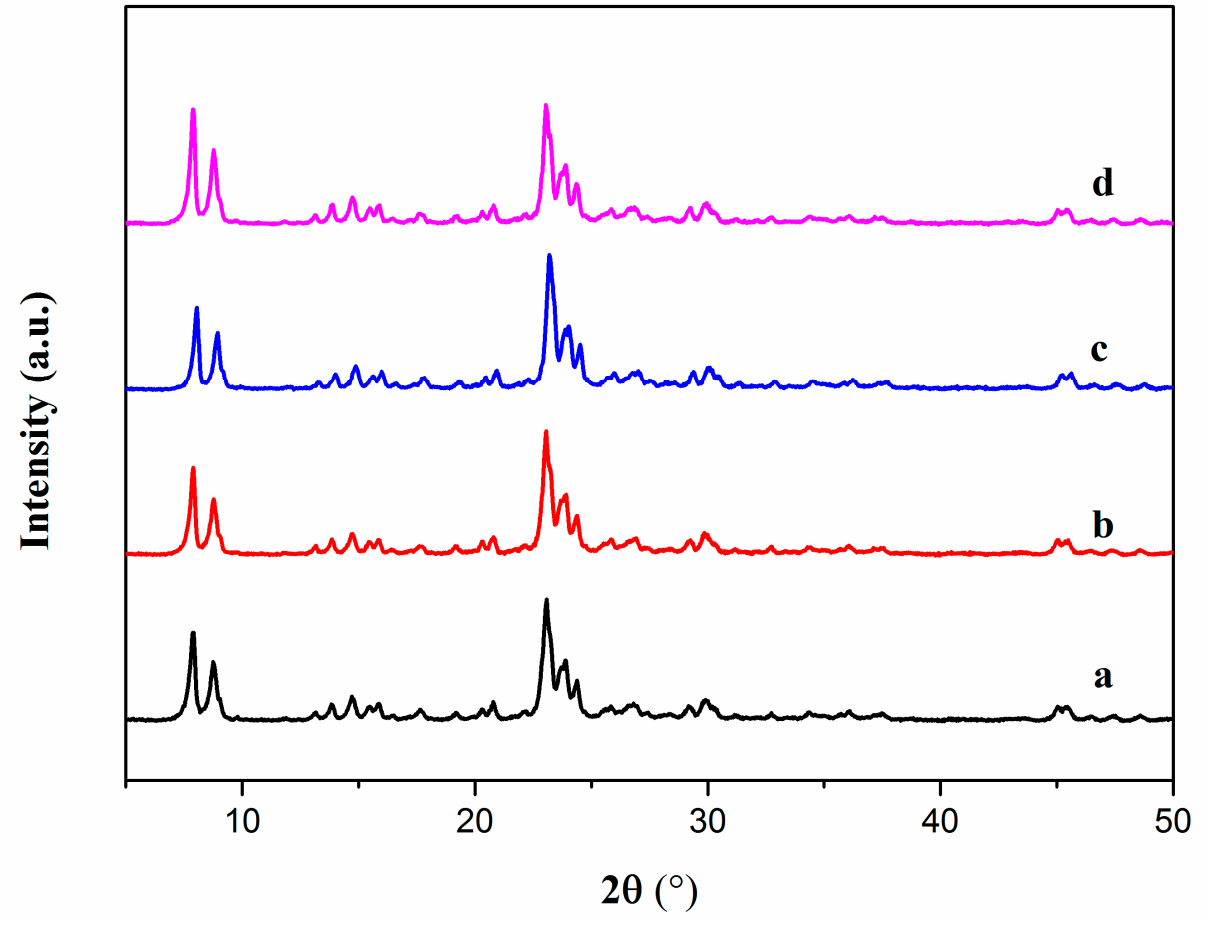

Figure 1. XRD patterns of HZSM- 5 catalysts with different $\mathrm{Na} / \mathrm{Al}$ ratios in synthesis gels. (a) $\mathrm{HZ}(0)$, (b) $\mathrm{HZ}(0.4)$, (c) $\mathrm{HZ}(0.8)$, and (d) $\mathrm{HZ}(1.1)$.

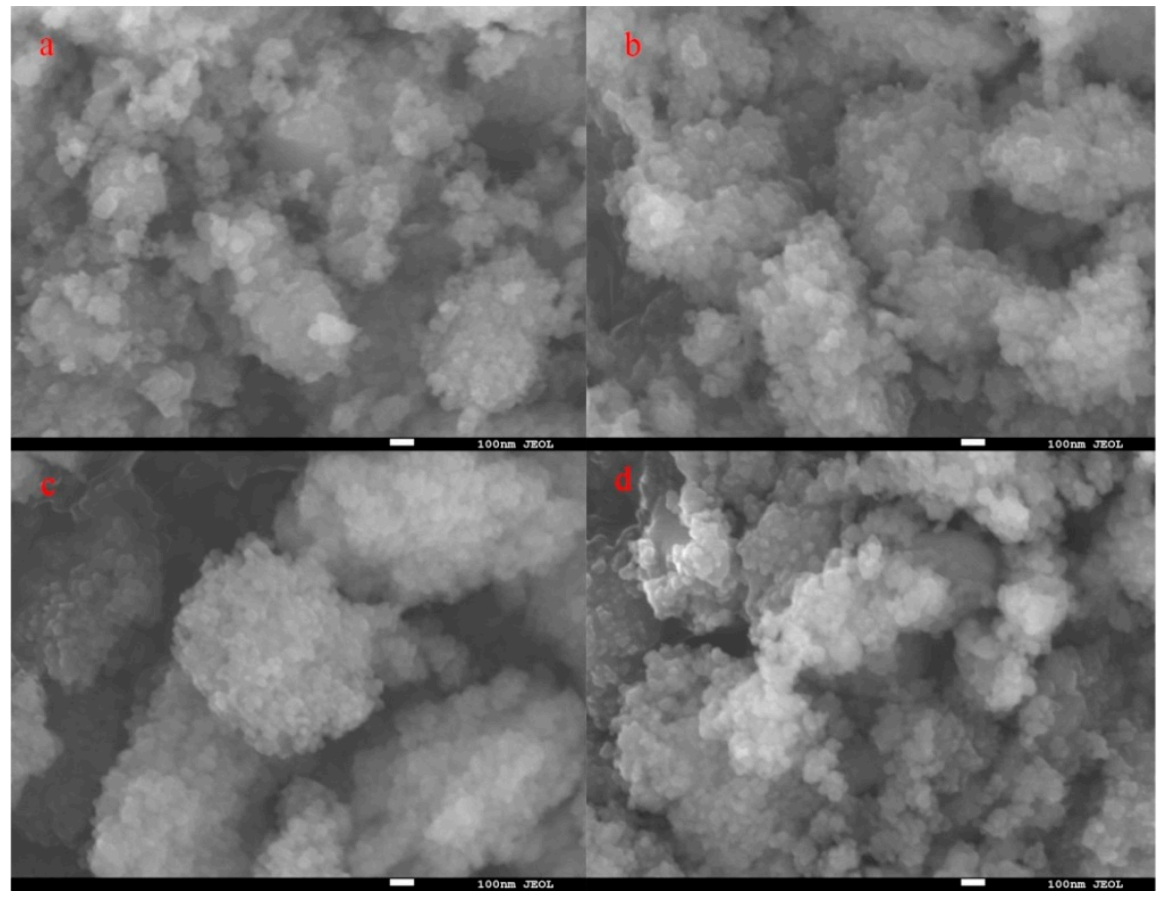

Figure 2. SEM images of the HZSM-5 catalysts with different $\mathrm{Na} / \mathrm{Al}$ ratios in synthesis gels. (a) $\mathrm{HZ}(0)$, (b) $\mathrm{HZ}(0.4)$, (c) $\mathrm{HZ}(0.8)$, and (d) $\mathrm{HZ}(1.1)$. 
Table 1. Crystallite and lattice parameters of catalysts.

\begin{tabular}{llllllll}
\hline \multirow{2}{*}{ Catalyst } & Crystal System & \multicolumn{6}{l}{ Lattice Parameters } \\
\cline { 3 - 8 } & & $\mathbf{a}(\AA)$ & $\mathbf{b}(\AA)$ & $\mathbf{c}(\AA)$ & $\boldsymbol{\alpha}$ & $\boldsymbol{\beta}$ & $\gamma$ \\
\hline $\mathrm{HZ}(0)$ & Orthorhombic & 20.091 & 19.899 & 13.384 & $90^{\circ}$ & $90^{\circ}$ & $90^{\circ}$ \\
$\mathrm{HZ}(0.4)$ & Orthorhombic & 20.102 & 19.902 & 13.389 & $90^{\circ}$ & $90^{\circ}$ & $90^{\circ}$ \\
$\mathrm{HZ}(0.8)$ & Orthorhombic & 20.090 & 19.905 & 13.389 & $90^{\circ}$ & $90^{\circ}$ & $90^{\circ}$ \\
$\mathrm{HZ}(1.1)$ & Orthorhombic & 20.098 & 19.907 & 13.390 & $90^{\circ}$ & $90^{\circ}$ & $90^{\circ}$ \\
\hline
\end{tabular}

The textual properties and chemical composition of the catalysts are summarized in Table 2. The catalysts have similar surface areas, pore volumes, pore size distributions and $\mathrm{Si} / \mathrm{Al}$ ratios.

Table 2. Elemental composition, textual properties and Al distribution of HZSM catalysts with different $\mathrm{Na} / \mathrm{Al}$ ratios in synthesis gels.

\begin{tabular}{|c|c|c|c|c|c|c|c|c|}
\hline Catalysts & $\mathrm{Si} / \mathrm{Al}^{\mathrm{a}}$ & $\mathrm{Si} / \mathrm{Al}_{\mathrm{F}}{ }^{\mathrm{b}}$ & $\underset{(\%)}{\mathrm{Al}_{\mathrm{F}} / \mathrm{Al}_{\text {total }}{ }^{\mathrm{b}}}$ & $\begin{array}{c}S_{\text {total }}{ }^{c} \\
\left(m^{2} g^{-1}\right)\end{array}$ & $\begin{array}{l}S_{\text {micro }}{ }^{d} \\
\left(m^{2} g^{-1}\right)\end{array}$ & $\begin{array}{c}V_{\text {total }} \mathrm{e} \\
\left(\mathrm{m}^{3} \mathrm{~g}^{-1}\right)\end{array}$ & $\begin{array}{l}V_{\text {micro }}{ }^{d} \\
\left(m^{3} g^{-1}\right)\end{array}$ & $\operatorname{PSD}^{f}(n m)$ \\
\hline $\mathrm{HZ}(0)$ & 42 & 43 & 97.2 & 420 & 256 & 0.45 & 0.11 & $0.772 \sim 0.879$ \\
\hline $\mathrm{HZ}(0.4)$ & 37 & 38 & 97.9 & 380 & 257 & 0.34 & 0.11 & $0.772 \sim 0.879$ \\
\hline $\mathrm{HZ}(0.8)$ & 38 & 40 & 95.7 & 363 & 267 & 0.28 & 0.12 & $0.772 \sim 0.879$ \\
\hline $\mathrm{HZ}(1.1)$ & 38 & 39 & 97.6 & 383 & 260 & 0.33 & 0.11 & $0.772 \sim 0.879$ \\
\hline
\end{tabular}

${ }^{a}$ Measured by ICP-OES. ${ }^{b}$ Determined by ${ }^{27} \mathrm{Al}$ MAS NMR. ${ }^{\mathrm{c}}$ Total specific surface area determined by BET equation. $\mathrm{d}$ Micropore surface area and micropore volume determined by $\mathrm{t}$-plot method. ${ }^{\mathrm{e}}$ Total pore volume determined by volume adsorbed at $\mathrm{p} / \mathrm{p}^{0}=0.99$. ${ }^{\mathrm{f}}$ Pore size distribution (PSD) was acquired by Density Functional Theory (DFT) method.

The ${ }^{27}$ Al-MAS NMR spectra of the catalysts are shown in Figure 3. All samples exhibit an intense peak at about $55 \mathrm{ppm}$, ascribed to tetrahedral framework $\mathrm{Al}$ and a weaker peak at approximately $0 \mathrm{ppm}$ attributed to octahedral extra-framework Al. It is noticed that the overwhelming majority of $\mathrm{Al}$ species is framework $\mathrm{Al}$. The $\mathrm{Si} / \mathrm{Al}_{\mathrm{F}}$ ratios of the catalysts acquired from ${ }^{27} \mathrm{Al}-\mathrm{MAS}$ NMR analysis closely match their $\mathrm{Si} / \mathrm{Al}$ ratios obtained by ICP-OES, indicating that almost all of $\mathrm{Al}$ atoms are present as $\mathrm{Al}_{\mathrm{F}}$ in the $\mathrm{ZSM}-5$ framework.

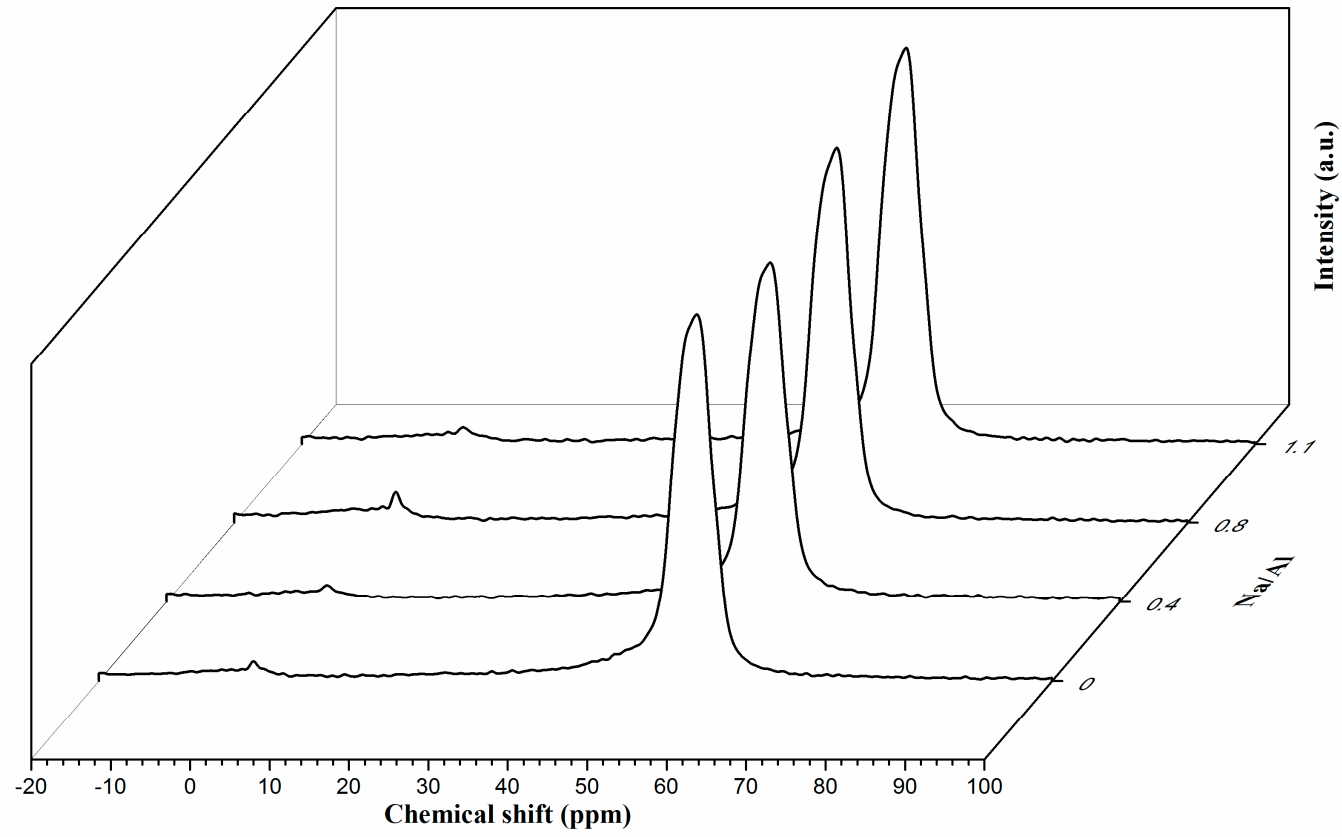

Figure 3. ${ }^{27} \mathrm{Al}-\mathrm{MAS}$ NMR spectra of $\mathrm{HZ}(0), \mathrm{HZ}(0.4), \mathrm{HZ}(0.8)$ and $\mathrm{HZ}(1.1)$ catalysts. 
Pyridine-adsorption infrared spectroscopy and $\mathrm{NH}_{3}$-TPD were employed to characterize the acidic properties of the catalysts, and the results are shown in Table 3. The catalysts possess similar numbers of Brönsted and Lewis/weak and strong acid sites, which is in good agreement of the $\mathrm{Si} / \mathrm{Al}_{\mathrm{F}}$ ratios. On the whole, the as-prepared catalysts exhibit similar morphology, textual properties, $\mathrm{Si} / \mathrm{Al}_{\mathrm{F}}$ ratio and acidic property.

Table 3. Acidic properties of the catalysts based on pyridine adsorption IR and $\mathrm{NH}_{3}$-TPD analysis.

\begin{tabular}{lllllll}
\hline \multirow{2}{*}{ Catalysts } & \multicolumn{2}{l}{ Acidity by $\mathbf{P y}$-IR $\left(\mathbf{m m o l} \mathbf{g}^{-\mathbf{1}}\right)^{\mathbf{a}}$} & \multicolumn{3}{l}{ Acidity by $\mathbf{N H}_{\mathbf{3}}$-TPD $\left(\mathbf{m m o l ~}^{\mathbf{- 1}}\right)^{\mathbf{b}}$} \\
\cline { 2 - 7 } & Brønsted & Lewis & Total & Strong & Weak & Total \\
\hline HZ(0) & 0.20 & 0.04 & 0.24 & 0.32 & 0.28 & 0.62 \\
HZ(0.4) & 0.22 & 0.04 & 0.26 & 0.37 & 0.27 & 0.64 \\
HZ(0.8) & 0.22 & 0.05 & 0.27 & 0.36 & 0.27 & 0.63 \\
HZ(1.1) & 0.21 & 0.03 & 0.24 & 0.36 & 0.28 & 0.64 \\
\hline
\end{tabular}

a The quantities of Brönsted and Lewis acid sites were calculated from the Py-IR spectra. ${ }^{b}$ The quantities of weak and strong acid sites determined by $\mathrm{NH}_{3}$-TPD were measured by the amounts of ammonia desorbed at $120-250$ and $250-500{ }^{\circ} \mathrm{C}$, respectively.

\subsection{Al distribution in the ZSM-5 Framework}

The proportions of framework $\mathrm{Al}$ species $\left(\mathrm{Al}_{\mathrm{F}}\right.$ pairs and single $\mathrm{Al}_{\mathrm{F}}$ ) in the different $\mathrm{Co}(\mathrm{II})-\mathrm{ZSM}-5$ samples are listed in Table 4. It is found that the fraction of $\mathrm{Al}_{\mathrm{F}}$ pairs in as-prepared catalysts increases from $54.2 \%$ to $64.4 \%$ with the increase of the $\mathrm{Na} / \mathrm{Al}$ molar ratio in the precursor gels from 0 to 0.8 , and then decreases with further increase of the $\mathrm{Na} / \mathrm{Al}$ ratio.

Table 4. Al distribution of Co-type ZSM-5 and HZSM-5.

\begin{tabular}{|c|c|c|c|c|c|c|c|c|}
\hline \multirow{2}{*}{ Samples } & \multicolumn{3}{|c|}{$\mathrm{Al}_{\mathrm{F}}$ Content $(\%)$} & \multicolumn{3}{|c|}{ Al Pair Distribution (\%) ${ }^{c}$} & \multicolumn{2}{|c|}{ Al Content by NMR (\%) } \\
\hline & $\mathrm{Al}_{\text {single }}{ }^{\mathrm{a}}$ & $\mathrm{Al}_{\text {pairs }}{ }^{\mathrm{a}}$ & $(2 \mathrm{Co}+\mathrm{Na}) / \mathrm{Al}^{\mathrm{b}}$ & $\alpha$ & $\beta$ & $\gamma$ & $\mathrm{Al}_{(54)}{ }^{\mathrm{d}}$ & $\mathrm{Al}_{(56)} \mathrm{d}$ \\
\hline Co/ZSM-5(0) & 45.8 & 54.2 & 0.99 & 14 & 64 & 22 & 31 & 29 \\
\hline Co/ZSM-5(0.4) & 42.1 & 57.9 & 0.99 & 10 & 66 & 24 & 33 & 27 \\
\hline Co/ZSM-5(0.8) & 35.6 & 64.4 & 0.96 & 10 & 65 & 25 & 33 & 27 \\
\hline Co/ZSM-5(1.1) & 40.4 & 59.6 & 0.97 & 7 & 68 & 25 & 31 & 27 \\
\hline
\end{tabular}

${ }^{\mathrm{a}}$ The contents of single $\mathrm{Al}$ and $\mathrm{Al}$ pairs $(2 \mathrm{Co} / \mathrm{Al})$ were calculated by the equations $\left[\mathrm{Al}_{\text {single }}\right]=\left[\mathrm{Al}_{\text {total }}\right]-2\left[\mathrm{Co}_{\max }\right]$ and $\left[\mathrm{Al}_{\text {pairs }}\right]=2\left[\mathrm{Co}_{\max }\right]$, where $\mathrm{Al}_{\text {total }}$ and $\mathrm{Co}_{\max }$ were determined by ICP-OES. ${ }^{\mathrm{b}}$ The $(2 \mathrm{Co}+\mathrm{Na}) / \mathrm{Al}$ ratio was determined by ICP-OES. ${ }^{c}$ The distribution of different $\mathrm{Al}$ pairs types $(\alpha, \beta$, and $\gamma)$ was determined by the deconvolution of Co(II) UV-vis-DR spectroscopy of Co-type ZSM-5 zeolites. ${ }^{\mathrm{d}}$ The contents of $\mathrm{Al}_{(54}$ ) and $\mathrm{Al}_{(56)}$ peaks were determined by deconvolution of the ${ }^{27} \mathrm{Al}$ MAS NMR spectra of H-ZSM- 5 catalysts.

$\mathrm{Co}(\mathrm{II}) \mathrm{UV}$-vis-DRS was employed to investigate the distribution of $\mathrm{Al}_{\mathrm{F}}$ pairs in Co/ZSM- 5 zeolites. The spectra were deconvoluted into seven bands of three $\mathrm{Co}$ (II) cations types coordinated with different $\mathrm{Al}_{\mathrm{F}}$ pairs T-sites. The relative concentrations of $\alpha$-type $\mathrm{Co}(\mathrm{II})$ ions in the straight channel, $\beta$-type $\mathrm{Co}(\mathrm{II})$ ions in the channel intersections and $\gamma$-type Co(II) ions in the sinusoidal channels are also given in Table 4. Most of $\mathrm{Al}_{\mathrm{F}}$ pairs are distributed in the channel intersection T-sites $(\sim 66 \%)$, and the relative concentrations of these three types T-sites shows the similar tendence in all of the catalysts.

${ }^{27} \mathrm{Al}$ MAS-NMR spectra were also employed to investigate the distribution of framework $\mathrm{Al}$ in HZSM- 5 by deconvolution of the broad peak ranging from 45 to 65 ppm $[17,21,25]$, as shown in Figure 4. Among the five peaks, the peak at $54 \mathrm{ppm}\left(\mathrm{Al}_{(54)}\right)$ and $56 \mathrm{ppm}\left(\mathrm{Al}_{(56)}\right)$ are related to the framework $\mathrm{Al}$ sites in the channel intersections and in straight and sinusoidal channels, respectively. The deconvolution results are listed in Table 4. Obviously, all the four samples exhibit a higher fraction of $\mathrm{Al}_{(54)}$, suggesting that more $\mathrm{Al}_{\mathrm{F}}$ site are distributed in channel intersections. This is in agreement with the Co(II) UV-vis-DRS results. 


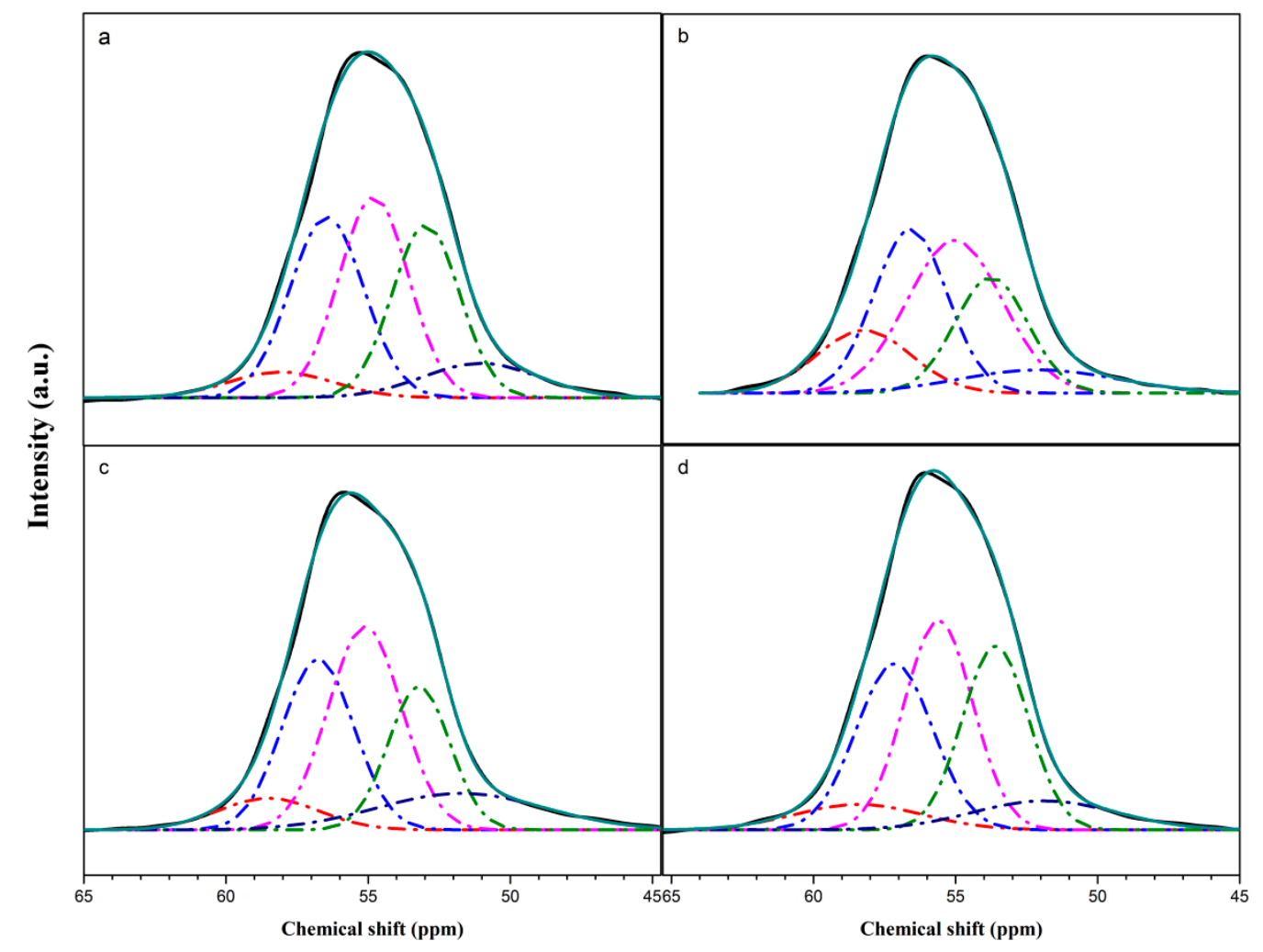

Figure 4. Deconvolution of the ${ }^{27} \mathrm{Al}-\mathrm{MAS}$ NMR spectra of (a) $\mathrm{HZ}(0)$, (b) HZ(0.4), (c) $\mathrm{HZ}(0.8)$ and (d) HZ(1.1) catalysts.

\subsection{Catalytic Performance}

\subsubsection{Catalytic Performance of HZSM-5 Zeolites in the Fixed-Bed Reactor}

The performance of the catalysts obtained in a fixed-bed reactor for propane aromatization is illustrated in Figure 5. The propane conversion and the aromatics selectivity exhibit the same trends along with time on stream (TOS) for all catalysts. The catalyst $\mathrm{HZ}(0.8)$ with more $\mathrm{Al}_{\mathrm{F}}$ pairs shows much higher propane conversion and aromatics selectivity than the other catalysts.

The selectivity of products in propane aromatization as a function of $\mathrm{Al}_{\mathrm{F}}$ pairs content is illuminated in Figure 6. It can be seen that the aromatics selectivity and hydrogen selectivity are increased, but the selectivity to $\mathrm{C}_{3}=-\mathrm{C}_{4}=$ olefins is decreased with the increasing $\mathrm{Al}_{\mathrm{F}}$ pairs content, while the selectivity to the cracking products (methane, ethane and ethene) does not differ too much. The aromatics selectivity to $\mathrm{HZ}(0.8)$ catalyst is 2.3 times higher than that of $\mathrm{HZ}(0)$ catalyst. What's more, the coke content of the used catalysts after $24 \mathrm{~h}$ TOS is also shown in Figure 6. It can be seen that coke content deposited in the catalysts is increased with the increasing of $\mathrm{Al}_{\mathrm{F}}$ pairs content, which is plotted similar to the tendence of aromatics selectivity.

Since the catalysts exhibit similar morphology, textual properties, $\mathrm{Si} / \mathrm{Al}_{\mathrm{F}}$ ratio and Brønsted acid sites numbers, the linear correlation between the selectivity of aromatics and olefins and $\mathrm{Al}_{\mathrm{F}}$ pairs contents reveals that the excellent catalytic performance of $\mathrm{HZ}(0.8)$ is probably contributed to by the higher fraction of $\mathrm{Al}_{\mathrm{F}}$ pairs in the catalyst.

The reaction pathway of propane aromatization on HZSM- 5 shown in Scheme 1 is well established [3]. The primary products of propane aromatization are propene and hydrogen from the dehydrogenation process, in parallel with the formation of methane and ethylene through protonic cracking reactions. Propene undergoes cyclo-oligomerization and hydrogen transfer reactions to generate aromatics and alkanes at Brønsted acid sites on HZSM- 5 catalysts. In the meantime, butene and pentene obtained from cracking of $C_{6}-C_{8}$ alkenes may oligomerize again to form $C_{6}-C_{8}$ alkenes. 
Therefore, the trend of selectivity to aromatics increase with the increase of $\mathrm{Al}_{\mathrm{F}}$ pair content accompanied with the decrease of olefins production may be attributed to the presence of more $\mathrm{Al}_{\mathrm{F}}$ pairs in the catalyst, which enhances the oligomerization of alkenes and cyclization reactions to promote the formation of aromatics. The following characterization and DFT calculation will demonstrate this hypothesis particularly.

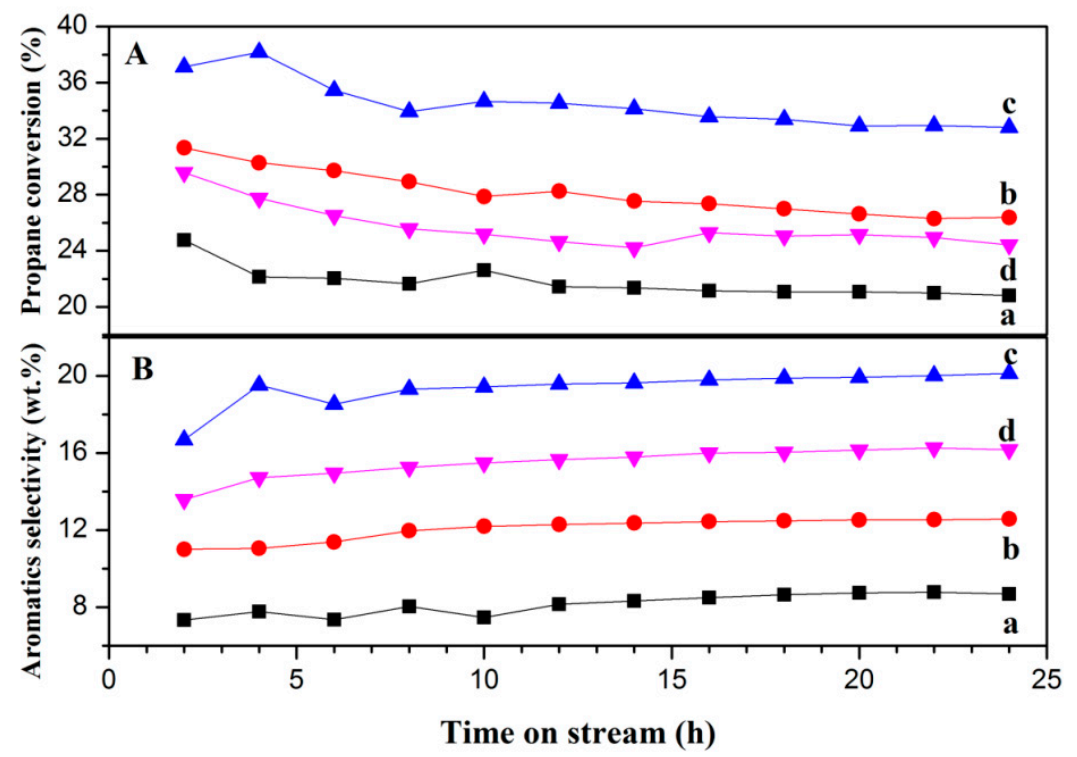

Figure 5. Propane conversion (A) and aromatics selectivity (B) with the time on stream (TOS) over HZSM-5 catalysts: $\mathrm{HZ(0)}(\mathrm{a}), \mathrm{HZ}(0.4)(\mathrm{b}), \mathrm{HZ}(0.8)$ (c) and $\mathrm{HZ}(1.1)(\mathrm{d})$. at $550{ }^{\circ} \mathrm{C}$ with weight hourly space velocity (WHSV) of propane being $0.6 \mathrm{~h}^{-1}$ and $\mathrm{N}_{2} / \mathrm{C}_{3} \mathrm{H}_{8}$ ratio being 2.5 in feedstock.

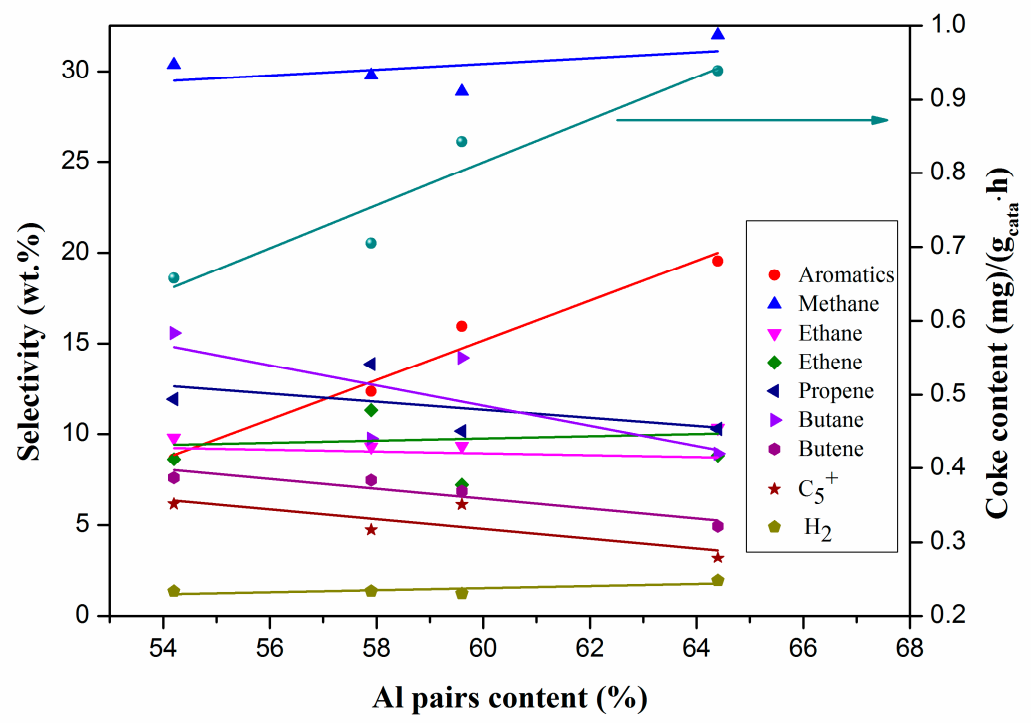

Figure 6. Product selectivity in propane aromatization at $20 \mathrm{~h}$ (TOS) and coke content in the used catalysts as a function of $\mathrm{Al}_{\mathrm{F}}$ pairs content in the framework of HZSM-5 catalysts. 


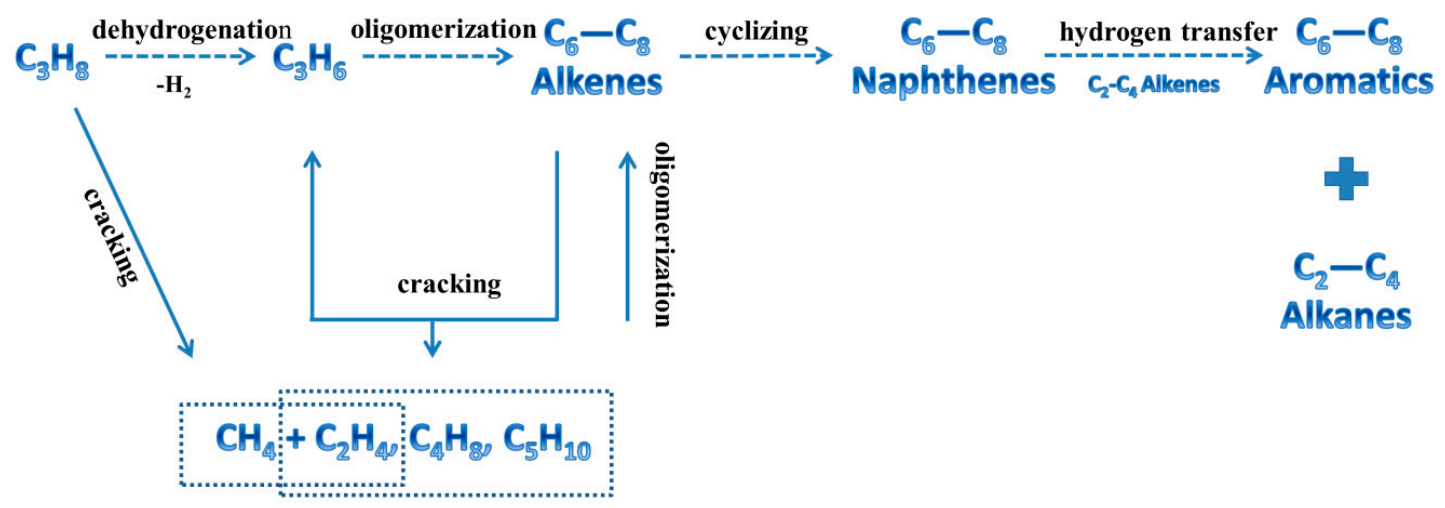

Scheme 1. Reaction pathway of propane aromatization on HZSM-5 catalysts [3].

\subsubsection{Micro Reactor Activity Estimation}

In order to estimate the initial products of $\mathrm{HZ}(0)$ and $\mathrm{HZ}(0.8)$ catalysts at low propane conversion, the gaseous products at a time-on-stream of $2 \mathrm{~min}$ on a micro reactor at $500{ }^{\circ} \mathrm{C}$ were on-line analyzed. Propane conversion are limited to $1.6 \%$ and $1.8 \%$ for $\mathrm{HZ}(0)$ and $\mathrm{HZ}(0.8)$ catalysts, respectively. The relative concentrations of gaseous products are compared in Table 5.

Table 5. Relative concentration of gaseous products for propane aromatization obtained in micro reactor experiment.

\begin{tabular}{lllll}
\hline \multirow{2}{*}{ Catalysts } & \multirow{2}{*}{ Aromatics Concentration $\left(\times \mathbf{1 0}^{\mathbf{4}} \mathbf{~}^{\mathbf{a}}\right.$} & \multicolumn{3}{l}{ Olefin Concentrations $^{\mathbf{a}}$} \\
\cline { 3 - 5 } & & Ethene & Propene & Butene \\
\hline $\mathrm{HZ}(0)$ & 7.71 & 0.924 & 0.159 & 0.015 \\
$\mathrm{HZ}(0.8)$ & 14.1 & 0.918 & 0.089 & 0.014 \\
\hline Normalized by methane concentration in propane aromatization at $500^{\circ} \mathrm{C}$ with the contact time of propane being $1.5 \mathrm{~s}$.
\end{tabular}

It can be seen that the relative concentration of propene for $\mathrm{HZ}(0.8)$ catalyst is much lower than that of $\mathrm{HZ}(0)$ catalyst; on the contrary, the relative concentration of aromatics for $\mathrm{HZ}(0.8)$ catalyst is much higher than that of $\mathrm{HZ}(0)$ catalyst. Propene as the primary product of propane aromatization undergoes cyclo-oligomerization and hydrogen transfer reactions to generate aromatics and alkanes at Brønsted acid sites (single $\mathrm{Al}_{\mathrm{F}}$ and $\mathrm{Al}_{\mathrm{F}}$ pairs) (Figure 7). Although both single $\mathrm{Al}_{\mathrm{F}}$ and $\mathrm{Al}_{\mathrm{F}}$ pairs sites can catalyze propene oligomerization, experimental results demonstrate that catalyst possessing higher $\mathrm{Al}_{\mathrm{F}}$ pairs content produces at the expense of propene and higher aromatics concentration in the products, which indicate that the presence of more $\mathrm{Al}_{F}$ pairs in the catalysts enhances the oligomerization of alkenes.

\subsubsection{Pulse Experiment of Propane Aromatization}

To investigate the initial products retained in the catalysts during propane aromatization, the catalytic performances of $\mathrm{HZ}(0)$ and $\mathrm{HZ}(0.8)$ catalysts were comparatively evaluated by pulse experiments at $500^{\circ} \mathrm{C}$. As illustrated in Figure 7 , the products deposited on catalysts are mainly benzene, toluene, xylenes, trimethylbenzenes (triMBs) and tetramethylbenzenes (tetraMBs). Comparing with the soluble coke of two catalysts, the $\mathrm{HZ}(0.8)$ catalyst possesses more aromatics, especially benzene, toluene, xylenes.

The results of GC-MS and micro reactor activity estimation indicate more $\mathrm{Al}$ pairs in the catalysts enhance the oligomerization of alkenes (especially propene) and produce more aromatics, which is consistent with the results of catalytic performance tests. 


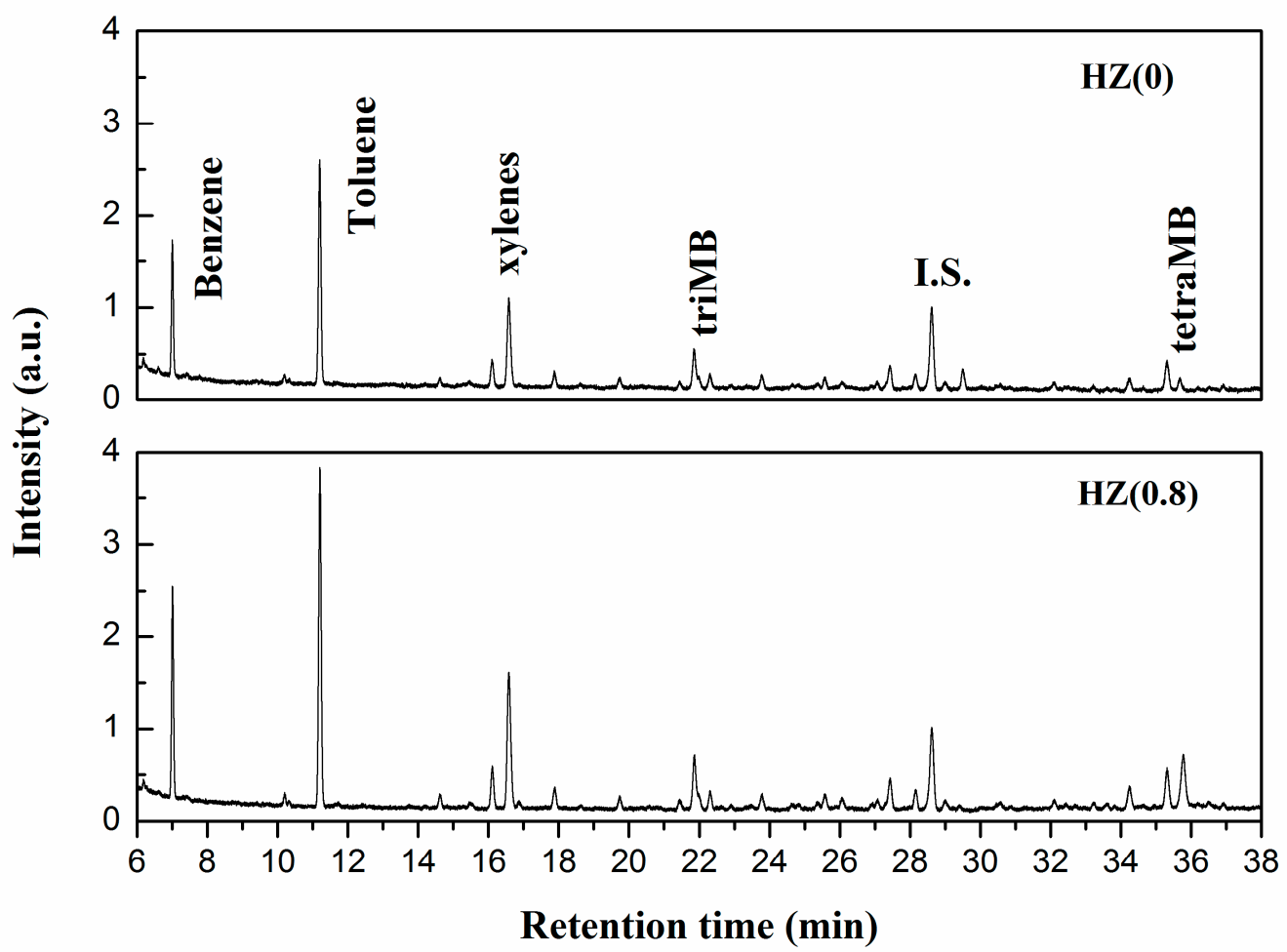

Figure 7. GC-MS spectra of the retained products in $\mathrm{HZ}(0)$ and $\mathrm{HZ}(0.8)$ catalysts after pulse of propane at $500{ }^{\circ} \mathrm{C}$, which are normalized to the I.S. intensity.

\subsubsection{Operando Diffuse Reflectance Ultraviolet-Visible (DR UV-vis) Spectra Experiment}

It is well-known that aromatization of propane goes through dehydrogenation, oligomerization, cyclization, and aromatization steps $[3,12,13,24]$. Taking into account that propane dehydrogenation, as the first step of propane aromatization, can be catalyzed by metal species such as $\mathrm{Zn}, \mathrm{Pt}$ and Ga etc., but the oligomerization and cyclization steps of light olefins are only catalyzed by zeolite acid sites, thus Operando diffuse reflectance ultraviolet-visible (DR UV-vis) spectra experiments were explored to investigate the formation of hydrocarbon species (mainly intermediate products) for propene conversion.

Figure 8 shows the Operando DR UV-vis spectra for conversion of propene at $250{ }^{\circ} \mathrm{C}$ over $\mathrm{HZ}(0)$ and HZ(0.8) catalysts, respectively. The bands located at 220 300 $\mathrm{nm}$ are attributed to cyclopentadienes, cyclohexadienes, neutral (methylated) benzenes, monoenyl carbocations and alkyl-substituted cyclopentenyl carbocations [26-30]. The bands centered at ca. 320 350 nm are ascribed to dienyl carbocations and low methylated benzene carbocations (such as xylenes and trimethylbenzenes) $[28,31,32]$. The bands at ca. $400 \sim 440 \mathrm{~nm}$ are assigned to highly methylated benzene carbocations (such as tetramethylbenzene, pentamethylbenzene and hexamethylbenzene) [28,30,31]. An increase in absorbance with increasing time-on-stream is observed, indicating the accumulation of the intermediate products on the zeolite catalysts during the conversion of propene. Compared with $\mathrm{HZ}(0)$ catalyst, more carbonaceous materials are formed on $\mathrm{HZ}(0.8)$ catalyst, especially those located at 250 350 nm assigned to the intermediates of aromatics originated from oligomerization and cyclization processes. The result is in good agreement with the catalytic performance tests. 

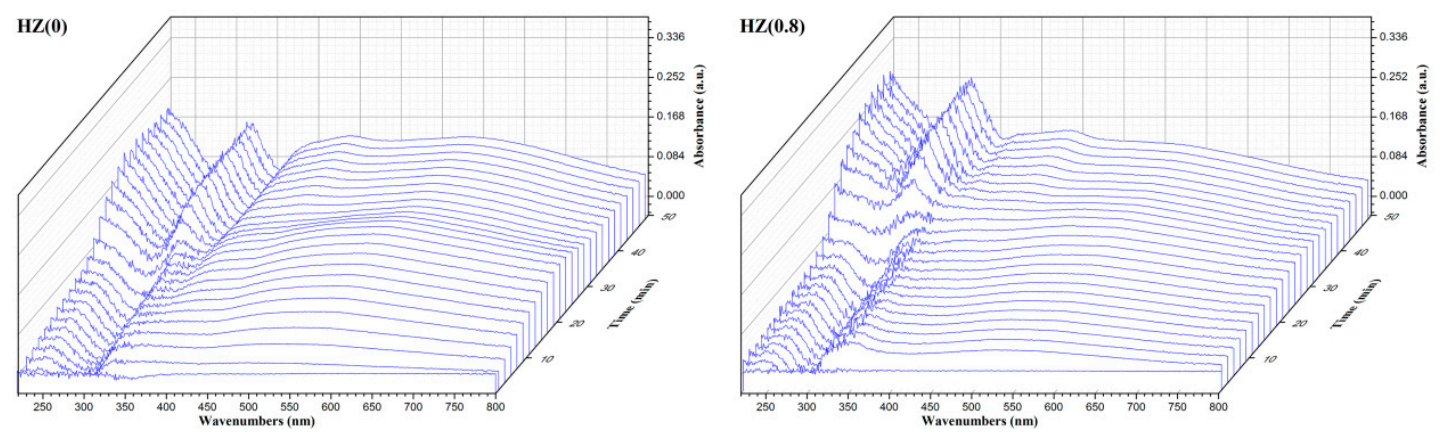

Figure 8. Operando DR UV-vis spectroscopy for conversion of propene over $\mathrm{HZ}(0)$ and $\mathrm{HZ}(0.8)$ catalysts at $250{ }^{\circ} \mathrm{C}$.

\subsection{Coke Analysis}

DR UV-vis and FTIR spectra were employed to analyze the coke species deposited in the used catalysts. The DR UV-vis spectra of the used HZ(0) and HZ(0.8) catalyst are shown in Figure 9. The bands at $\sim 330$ and $\sim 410 \mathrm{~nm}$ are ascribed to dienyl carbocations/low methylated benzene carbocations and highly methylated benzene carbocations, respectively [30]. As for the band at $\sim 530 \mathrm{~nm}$, it may be caused by phenanthrene, anthracene carbocations, deposited pyrene and/or more benzene rings-fused aromatic molecules [30,31]. It is noticed that the coke species are similar for these two catalysts. However, one cannot determine precise differences between the different reaction species with TOS from DR UV-vis spectra.

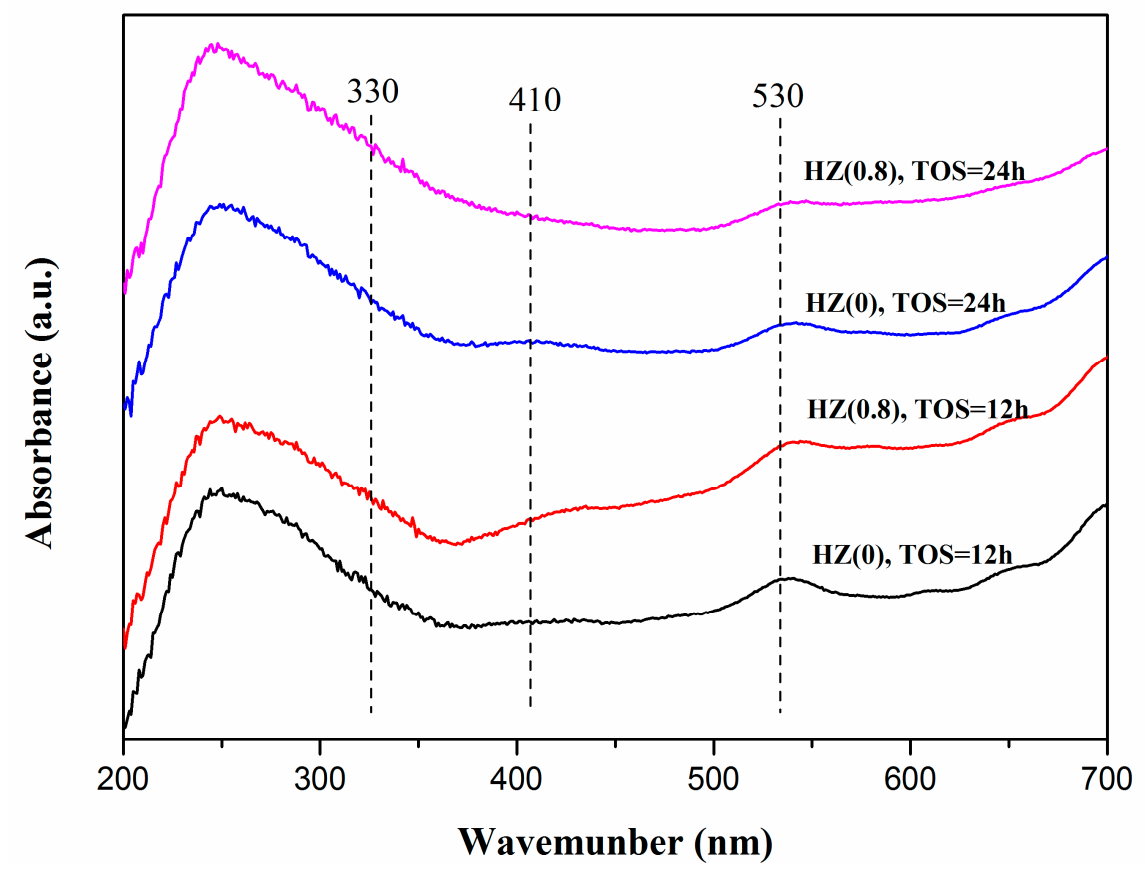

Figure 9. DR UV-vis spectra of the catalysts obtained in different TOS.

In order to acquire more information of reaction species deposited in the used catalysts at different TOS, FTIR spectroscopy was carried out. Figure 10 depicts the FTIR spectra of the used HZ(0) and $\mathrm{HZ}(0.8)$ catalyst after reactions at different TOS (12 and $24 \mathrm{~h}$ ), denoted as HZ(0)-12, HZ(0)-24, HZ(0.8)-12 and HZ(0.8)-24, respectively. 

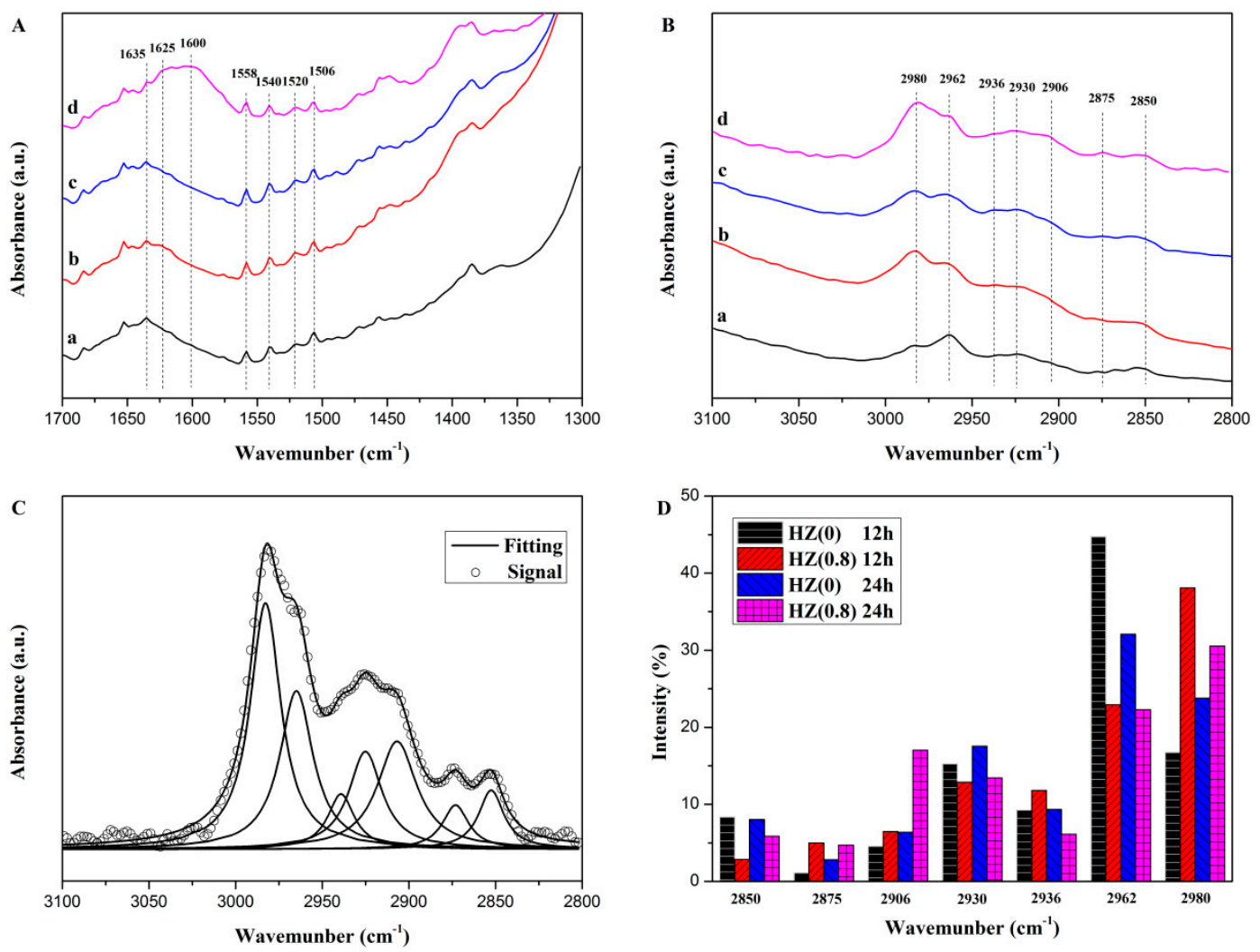

Figure 10. FTIR spectra of the used $\mathrm{HZ}(0)$ and $\mathrm{HZ}(0.8)$ catalysts after propane aromatization for 12 and $24 \mathrm{~h}$ at $550{ }^{\circ} \mathrm{C}$ with WHSV of propane being $0.6 \mathrm{~h}^{-1}$ and $\mathrm{N}_{2} / \mathrm{C}_{3} \mathrm{H}_{8}$ ratio being 2.5 in feedstock in the region of (A) 1700-1300 cm-1 and (B) 3100-2800 cm $\mathrm{cm}^{-1}$ for (a) HZ(0)-12, (b) HZ(0.8)-12, (c) HZ(0)-24, (d) HZ(0.8)-24; (C) Deconvoluted CH-region (3100-2800 $\mathrm{cm}^{-1}$ ) spectrum of HZ(0.8)-24; (D) Fraction of intensity (calculated using the area of the peaks in (B) of several characteristic vibrational bands of the catalysts in the FTIR region $2800-3100 \mathrm{~cm}^{-1}$.

According to previous researches [24,32-35], the bands at $1300-1500 \mathrm{~cm}^{-1}$ are not assigned, as a variety of bands overlapped in this region; the band at approximately 1506, 1520, 1540, $1558 \mathrm{~cm}^{-1}$ are assigned to monoenyl carbenium ions, non-condensed aromatics, alkylnaphthalenes and/or polyphylenes; the band at $\sim 1600 \mathrm{~cm}^{-1}$ is attributed to polyaromatics and/or condensed coke; another two bands at 1625 and $1635 \mathrm{~cm}^{-1}$ are due to double bonds or olefins. As shown in Figure 10A, the band at $1625 \mathrm{~cm}^{-1}$ are increased slightly for $\mathrm{HZ}(0.8)-12$ sample compared to sample HZ(0)-12; the band at 1600 and $1625 \mathrm{~cm}^{-1}$ are rasied remarkable for $\mathrm{HZ}(0.8)-24$ compared with $\mathrm{HZ}(0)-24$, indicating that $\mathrm{HZ}(0.8)$ catalyst has more polyaromatics or double bonds coke species than $\mathrm{HZ}(0)$ catalyst at the same TOS. For HZ(0.8) catalysts at different TOS, polyaromatics and double bonds coke species are increased with increasing reaction time. As mentioned above, these two catalysts have similar textual properties and exhibit similar morphology, so coke contents were not affected by diffusion of products. This phenomenon is contributed to the higher fraction of $\mathrm{Al}_{\mathrm{F}}$ pairs in the catalyst, which enhances the oligomerization of alkenes and cyclization reactions to promote the formation of aromatics.

The bands between 2800 and $3100 \mathrm{~cm}^{-1}$ are assigned to aliphatic and aromatic $\mathrm{C}-\mathrm{H}$ vibrations. As shown in Figure 10B, the bands in $3000-3100 \mathrm{~cm}^{-1}$ ascribed to aromatic $\mathrm{C}-\mathrm{H}$ vibration are not observed in the used catalysts, probably because most of the deposited coke species are fused-ring aromatics and/or highly branched cokes, which exhibit low $\mathrm{C}-\mathrm{H}$ intensity $[33,34]$.

In order to quantify the coke vibrations, the spectrum of each sample is deconvoluted into several Lorentzian peaks [32,35]: $2850 \mathrm{~cm}^{-1},-\mathrm{CH}_{2}$ groups related to symmetric paraffinic hydrocarbons; $2875 \mathrm{~cm}^{-1},-\mathrm{CH}_{3}$ groups related to symmetric paraffinic hydrocarbons; $2906 \sim 2937 \mathrm{~cm}^{-1},-\mathrm{CH}$ and $-\mathrm{CH}_{2}$ groups of asymmetric paraffinic hydrocarbons; $2962 \mathrm{~cm}^{-1},-\mathrm{CH}_{3}$ groups of asymmetric paraffinic 
hydrocarbons; $2980 \mathrm{~cm}^{-1},-\mathrm{CH}$ and $-\mathrm{CH}_{2}$ groups related to symmetric olefinic hydrocarbons with high carbon number. An example of the deconvolution is depicted in Figure 10C where the region of 2800-3100 $\mathrm{cm}^{-1}$ is plotted for the $\mathrm{HZ}(0.8)-24$ sample. As shown in Figure 10D, the band intensities at $2962 \mathrm{~cm}^{-1}$ of used HZ(0) catalyst are much higher than that of used HZ(0.8) catalyst at the same TOS, while the band intensity at $2980 \mathrm{~cm}^{-1}$ show the opposite, indicating that $\mathrm{HZ}(0.8)$ catalyst possesses less paraffinic hydrocarbons species and more olefinic hydrocarbons species with high carbon number. With the increase of TOS, the band intensity at $2980 \mathrm{~cm}^{-1}$ is increased for the used $\mathrm{HZ}(0.8)$ catalysts, but it is decreased for the used $\mathrm{HZ}(0)$ catalysts. As mentioned above, this band at $2980 \mathrm{~cm}^{-1}$ is assigned to $-\mathrm{CH}$ and $-\mathrm{CH}_{2}$ groups related to symmetric olefinic hydrocarbons with high carbon number, which is oligomerized from the oligomerization of lower olefins in the propane aromatization. This result suggested that the oligomer olefins are decreased on $\mathrm{HZ}(0.8)$ catalyst with the time on stream. Combined with the result obtained from Figure $10 \mathrm{~A}(\mathrm{~b}, \mathrm{~d})$, it is convinced that the higher olefins have been further converted into aromatics on $\mathrm{HZ}(0.8)$ catalyst with the time on stream.

This FTIR analysis of coke species on the used catalysts demonstrates that higher $\mathrm{Al}_{\mathrm{F}}$ pairs content in the catalyst promotes the oligomerization and cyclization reactions of olefins and leads to the production of more aromatics, which is in good agreement with the results of the catalytic performance tests and Operando DR UV-vis spectra experiments.

\subsection{DFT Calculations}

DFT calculations were used to further evaluate the influence of the structure of single $\mathrm{Al}_{\mathrm{F}}$ and $\mathrm{Al}_{\mathrm{F}}$ pairs on the propane aromatization process. Here, 1-hexyl cation was applied as reactant to form benzene, because 1-hexyl cation is a typical precursor species (formed by propene [36]) in propane aromatization. The aromatization of 1-hexyl cation undergoes cyclization, hydride transfer, and dehydrogenation to produce aromatics. As shown in Scheme 2, 1-hexyl cation firstly produces the cyclohexane through cyclization reaction (TS1). Then, the hydride transfer reaction (TS2) between cyclohexane and propoxy leads to the formation of cyclohexyl carbenium ion and propane. After that, the cyclohexyl carbenium ion is converted to benzene by repeated deprotonations and hydride transfer reactions (TS3 and TS4). The calculated kinetic and thermodynamic results are given in Table 6. It should be noticed the deprotonation reaction are not considered because the free energy barrier of deprotonation reaction is quite low, in comparison with that of cyclization and hydride transfer reactions [37].

It was found that the $\mathrm{ZSM}-5$ zeolite containing $\mathrm{Al}_{\mathrm{F}}$ pairs shows lower free energy barrier and higher rate constants of cyclization $\left(171 \mathrm{~kJ} \mathrm{~mol}^{-1}, 2.50 \times 10^{2} \mathrm{~s}^{-1}\right)$ and hydride transfer $\left(145-159 \mathrm{~kJ} \mathrm{~mol}^{-1}\right.$, $\left.1.38 \times 10^{3}-1.03 \times 10^{4} \mathrm{~s}^{-1}\right)$ reactions than the ZSM-5 zeolite containing single $\mathrm{Al}\left(176 \mathrm{~kJ} \mathrm{~mol}^{-1}\right.$ and $1.12 \times 10^{2} \mathrm{~s}^{-1}$ for cyclization, and $156-166 \mathrm{~kJ} \mathrm{~mol}^{-1}$ and $5.11 \times 10^{2}-2.06 \times 10^{3} \mathrm{~s}^{-1}$ for hydride transfer). Meanwhile, the low free energy barriers for cyclization and hydride transfer steps on ZSM-5 zeolite containing $\mathrm{Al}_{\mathrm{F}}$ pairs, is mainly contributed to their lower enthalpy barriers. These results demonstrate that the structure of $\mathrm{Al}_{\mathrm{F}}$ pairs in the framework of HZSM-5 zeolite shows stronger electrostatic stabilization effect on the transition states than that of single $\mathrm{Al}_{\mathrm{F}}[38,39]$. Therefore, it can better promote the aromatization process and produce more aromatic species.

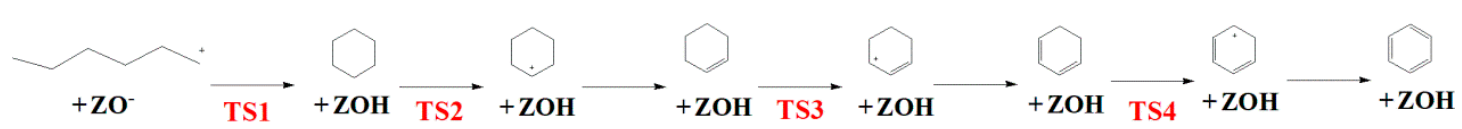

Scheme 2. Reaction network for the formation of benzene in the transition period for propane aromatization over $\mathrm{H}-\mathrm{ZSM}-5$ catalysts. $\mathrm{ZOH}$ and $\mathrm{ZO}^{-}$represent the protonated and deprotonated acid sites of zeolite, respectively. 
Table 6. Calculated free energy barriers $\left(\Delta G_{\text {int }}{ }^{\neq}\right)$, rate constants $(k)$, enthalpy barriers $\left(\Delta H_{\text {int }}{ }^{\neq}\right)$, and entropy losses $\left(-T \Delta S_{\text {int }}{ }^{\neq}\right)$, as well as reaction free energies $\left(\Delta G_{R}\right)$ at $823 \mathrm{~K}$ for each reaction step in the formation of benzene in the transition period for propane aromatization over H-ZSM-5.

\begin{tabular}{|c|c|c|c|c|c|}
\hline Step & $\Delta G_{\mathrm{int}} \neq\left(\mathrm{kJ} \mathrm{mol}{ }^{-1}\right)$ & $k\left(\mathrm{~s}^{-1}\right)$ & $\Delta H_{\mathrm{int}^{*}}{ }^{\neq}\left(\mathrm{kJ} \mathrm{mol}^{-1}\right)$ & $-T \Delta S_{\mathrm{int}^{\prime}} \neq\left(\mathrm{kJ} \mathrm{mol}^{-1}\right)$ & $\Delta G_{\mathrm{R}}\left(\mathrm{kJ} \mathrm{mol}^{-1}\right)$ \\
\hline \multicolumn{6}{|c|}{ Single $\mathrm{Al}_{\mathrm{F}}$} \\
\hline TS1 & 176 & $1.12 \times 10^{2}$ & 157 & 19 & -19 \\
\hline TS2 & 158 & $1.75 \times 10^{3}$ & 160 & -2 & 105 \\
\hline TS3 & 156 & $2.06 \times 10^{3}$ & 151 & 5 & 9 \\
\hline TS4 & 166 & $5.11 \times 10^{2}$ & 158 & 8 & -1 \\
\hline \multicolumn{6}{|c|}{$\mathrm{Al}_{\mathrm{F}}$ pairs } \\
\hline TS1 & 171 & $2.50 \times 10^{2}$ & 151 & 20 & -28 \\
\hline TS2 & 145 & $1.03 \times 10^{4}$ & 154 & -9 & 108 \\
\hline TS3 & 149 & $5.34 \times 10^{3}$ & 143 & 6 & 27 \\
\hline TS4 & 159 & $1.38 \times 10^{3}$ & 149 & 10 & 10 \\
\hline
\end{tabular}

\section{Experimental Section}

\subsection{Catalyst Preparation}

The ZSM- 5 zeolites with different contents of $\mathrm{Al}_{\mathrm{F}}$ pairs were synthesized by adjusting the $\mathrm{Na} / \mathrm{Al}$ molar ratios $(0,0.4,0.8$ and 1.1) in the precursor gels. The Na-free gel contained tetraethyl orthosilicate (TEOS), tetrapropylammonium hydroxide (TPAOH, $25 \mathrm{wt} \%$ ) and aluminum nitrate $\left(\mathrm{Al}\left(\mathrm{NO}_{3}\right)_{3}\right)$ in a composition proportion of $1 \mathrm{SiO}_{2}: 0.0125 \mathrm{Al}_{2} \mathrm{O}_{3}: 0.4 \mathrm{TPAOH}: 66 \mathrm{H}_{2} \mathrm{O}$. The chemical composition of $\mathrm{Na}^{+}$-containing gels was $1 \mathrm{SiO}_{2}: 0.0125 \mathrm{Al}_{2} \mathrm{O}_{3}: 0.4 \mathrm{TPAOH}: \mathrm{x} \mathrm{NaCl}: 36 \mathrm{H}_{2} \mathrm{O}$, where $\mathrm{x}$ was 0.01 , 0.02 and 0.0275 , corresponding to the samples with $\mathrm{Na} / \mathrm{Al}$ ratios of $0.4,0.8$ and 1.1 , respectively. The gel was stirred at room temperature for $12 \mathrm{~h}$ before being sealed into a Teflon-lined autoclave. After crystallation at $170^{\circ} \mathrm{C}$ for $5 \mathrm{~d}$, the material was centrifugated, washed with water, dried overnight at $100{ }^{\circ} \mathrm{C}$, and calcined at $560^{\circ} \mathrm{C}$ for $10 \mathrm{~h}$ in air to obtain the parent NaZSM-5 zeolite.

H-form ZSM- 5 was prepared by repeated ion exchanging NaZSM- 5 zeolite with $\mathrm{NH}_{4} \mathrm{NO}_{3}$ aqueous solution $\left(1 \mathrm{M}, \mathrm{m}\right.$ (liquid) $/ \mathrm{m}$ (solid) $=40$ ) at $80^{\circ} \mathrm{C}$ for $4 \mathrm{~h}$, which was then calcined at $550{ }^{\circ} \mathrm{C}$ for $6 \mathrm{~h}$ in air. The samples were donated as $\mathrm{HZ}(m)$, where $m$ is the $\mathrm{Na} / \mathrm{Al}$ molar ratio in the precusor gel. The normal $\mathrm{Si} / \mathrm{Al}$ molar ratio of all samples was 40 .

To investigate the $\mathrm{Al}$ distribution in the framework of ZSM-5 zeolites, Co-ZSM- 5 samples were prepared by reverse ion exchanging of HZSM- 5 with $\mathrm{NaCl}$ aqueous solution $(1.0 \mathrm{M})$ at $80^{\circ} \mathrm{C}$ for $6 \mathrm{~h}$ and subsequent ion exchanging of NaZSM- 5 three times with a $\mathrm{Co}\left(\mathrm{NO}_{3}\right)_{2}$ aqueous solution $(0.05 \mathrm{M})$ at $80{ }^{\circ} \mathrm{C}$ for $12 \mathrm{~h}$ under stirring condition. The Co-ZSM- 5 sample was rinsed with distilled water three times, dried in air and calcined at $500{ }^{\circ} \mathrm{C}$ for $4 \mathrm{~h}$ in air [17].

\subsection{Catalyst Characterization}

X-ray powder diffraction (XRD) patterns were collected on a MiniFlex II desktop X-ray diffractometer (Rigaku, Japan) with $\mathrm{Cu} K \alpha$ radiation $(0.154 \mathrm{~nm}, 30 \mathrm{kV}, 15 \mathrm{~mA})$. The cell parameters of the catalysts were obtained by Rietveld refinement of XRD data using X'Pert HighScore Plus software (PANalytical, Holland).

The scanning electron microscopy (SEM) images were taken on a field emission scanning electron microscope (FESEM, JSM 7001-F, JEOL, Japan).

Nitrogen adsorption/desorption measurements were performed at $77 \mathrm{~K}$ on a TriStar II 3020 gas adsorption analyzer (Micromeritics, Norcross, GA, USA). Prior to the measurement, the zeolite sample was degassed at $300^{\circ} \mathrm{C}$ for $8 \mathrm{~h}$. The total specific surface area was calculated by Brunauer-Emmett-Teller (BET) method; the total pore volume was estimated from the volume of nitrogen adsorbed at a nitrogen relative pressure of 0.99 . The pore size distribution was acquired by the Density Functional Theory (DFT) method. The micropore volume and external surface area were measured by t-plot method. The micropore surface area was obtained from the difference between the total pore surface area and the external surface area. 
The chemical composition of the catalysts was determined by Inductively Coupled Plasma Optical Emission Spectrometer (ICP-OES, Thermo iCAP6300, Thermo Fisher Scientific, Waltham, MA, USA).

The ultraviolet-visible diffuse reflectance spectra (UV-vis-DRS) were measured on an Cary 5000 UV-vis-NIR spectrophotometer (Agilent, Wilmington, DE, USA) equipped with a poly (tetrafluoroethylene) integrating sphere. The UV-vis DRS of $\mathrm{Co}^{2+}$-exchanged samples were collected at room temperature after dehydration at $773 \mathrm{~K}$ for $5 \mathrm{~h}$ under high vacuum condition $\left(<10^{-1} \mathrm{~Pa}\right)$. The concentration of $\mathrm{Al}_{\text {single }}$ and $\mathrm{Al}_{\text {pairs }}$ was calculated using the following equations:

$$
\begin{gathered}
{\left[\mathrm{Al}_{\text {single }}\right]=\left[\mathrm{Al}_{\text {total }}\right]-2\left[\mathrm{Co}_{\max }\right]} \\
{\left[\mathrm{Al}_{\text {pairs }}\right]=2\left[\mathrm{Co}_{\max }\right]}
\end{gathered}
$$

where $\left[\mathrm{Al}_{\text {total }}\right]$ and $\left[\mathrm{Co}_{\max }\right]$ are the $\mathrm{Al}$ content and Co content in Co-type ZSM- 5 zeolites, respectively, and both were determined by ICP-OES.

FTIR spectra were measured on a Tensor 27 spectrometer (Bruker, Germany) in the range $400-4000 \mathrm{~cm}^{-1}$ with a resolution of $4 \mathrm{~cm}^{-1}$ by the conventional $\mathrm{KBr}$ method at room temperature and $10^{-2} \mathrm{~Pa}$.

Pyridine-adsorption infrared (Py-IR) spectra were measured on a Bruker Tensor 27 FTIR spectrometer. Before collecting the spectrum, the self-supported sample wafer was evacuated at $350^{\circ} \mathrm{C}$ and $10^{-2} \mathrm{~Pa}$ for $2 \mathrm{~h}$, and cooled to room temperature subsequently. Then pyridine vapor was introduced into the sample cell for $1 \mathrm{~h}$. The spectrum was collected after evacuation of the sample wafer at $150{ }^{\circ} \mathrm{C}$ for $1 \mathrm{~h}$. The contents of Brønsted and Lewis acid sites were estimated using the following equation by integrating the vibration bands at 1540 and $1450 \mathrm{~cm}^{-1}$, respectively:

$$
C=\frac{A}{\varepsilon} \times \frac{S}{M} \times 1000
$$

where $C$ is the concentration of Brønsted and Lewis acid sites $\left(\mu \mathrm{mol} \mathrm{g}{ }^{-1}\right), A$ is the area of the vibration band at 1540 or $1450 \mathrm{~cm}^{-1}, S$ is the surface area of the sample wafer $\left(1.33 \mathrm{~cm}^{2}\right), \varepsilon$ is the molar extinction coefficient (1.13 and $1.28 \mathrm{~cm} \mathrm{\mu mol}^{-1}$ for Brønsted and Lewis acid sites, respectively), and $M$ is the mass of sample (mg) [26].

Temperature-programmed desorption of $\mathrm{NH}_{3}\left(\mathrm{NH}_{3}\right.$-TPD) was performed on an AutoChem II 2920 chemisorption analyzer from Micromeritics (USA). A catalyst sample $(0.1 \mathrm{~g})$ was first pretreated at $550{ }^{\circ} \mathrm{C}$ for $2 \mathrm{~h}$ in $\mathrm{Ar}$ stream $(30 \mathrm{~mL} / \mathrm{min})$ and then cooled to $120^{\circ} \mathrm{C}$. Then gaseous $\mathrm{NH}_{3}(5 \mathrm{vol} \%$ in argon, $30 \mathrm{~mL} / \mathrm{min}$ ) was introduced into the sample tube for $30 \mathrm{~min}$ to saturated adsorb of $\mathrm{NH}_{3}$ on the catalyst. After that, the physically adsorbed $\mathrm{NH}_{3}$ was removed by $\mathrm{Ar}(30 \mathrm{~mL} / \mathrm{min})$ at $120^{\circ} \mathrm{C}$ for $2 \mathrm{~h}$. To get the $\mathrm{NH}_{3}$-TPD profile, the catalyst was then heated from 120 to $500^{\circ} \mathrm{C}$ at a ramp of $10^{\circ} \mathrm{C} / \mathrm{min}$; the desorption signal was recorded by a thermal conductivity detector (TCD).

Thermal gravimetric analysis (TGA) of the used catalysts were performed on a Rigaku Thermo plus Evo TG 8120 (Tokyo, Japan) instrument at a heating rate of $10^{\circ} \mathrm{C} / \mathrm{min}$ in an air flow $(30 \mathrm{~mL} / \mathrm{min}$ ). The coke content deposited on the catalysts was determined by weight loss between 400 and $700{ }^{\circ} \mathrm{C}$.

${ }^{27} \mathrm{Al}$ MAS NMR spectra were measured on Bruker Avance III $600 \mathrm{MHz}$ Wide Bore spectrometer (Bruker, Germany) operating at a magnetic field of $14.2 \mathrm{~T}$. The spectra were acquired at a spinning rate of $13 \mathrm{kHz}$ with a $\pi / 12$ pulse width of $1.0 \mu$ s and a recycle delay of $1 \mathrm{~s}$.

Operando diffuse reflectance ultraviolet-visible (DR UV-vis) spectra were obtained using an Agilent Cary 5000 UV-vis-NIR spectrophotometer (Agilent, Wilmington, DE, USA). The self-supporting sample wafer $(100 \mathrm{mg})$ was placed in a self-made quartz cell. The samples were pretreated at $250{ }^{\circ} \mathrm{C}$ under a flow of $\operatorname{Ar}(30 \mathrm{~mL} / \mathrm{min})$ at atmospheric pressure for $2 \mathrm{~h}$. The spectra were obtained at $250^{\circ} \mathrm{C}$ under a flow of propene $(1 \mathrm{~mL} / \mathrm{min})$ at atmospheric pressure. 


\subsection{Catalysis tests}

\subsubsection{Propane Conversion in a Fixed-Bed Reactor}

The catalytic test for propane aromatization was carried out on a fixed-bed reactor (i.d. $10 \mathrm{~mm}$ ) at atmospheric pressure. Fixed-bed reaction process was illustrated in Figure 11. Typically, $2.3 \mathrm{~g}$ of catalyst (20-40 mesh) was used per round. The reaction was carried out at $550{ }^{\circ} \mathrm{C}$ in a propane/nitrogen flow ( $42 \mathrm{~mL} / \mathrm{min}$ ) with a $\mathrm{N}_{2} / \mathrm{C}_{3} \mathrm{H}_{8}$ molar ratio of 2.5 viz. a weight hourly space velocity (WHSV) of propane being $0.6 \mathrm{~h}^{-1}$. The gas and liquid products were separated with a cold trap. The gaseous products including $\mathrm{H}_{2}, \mathrm{CH}_{4}$, light olefins and paraffins were analyzed on-line on a gas chromatograph (GC) (Agilent 7890A) equipped with a thermal conductivity detector (TCD, MoleSieve 5A column, $3 \mathrm{~m} \times 1 / 16$ inch $\times 1 \mu \mathrm{m}$ ) and two flame ionization detectors (FIDs, GC-OxyPlot column, $10 \mathrm{~m} \times 530 \mu \mathrm{m}$ $\times 10 \mu \mathrm{m} ; \mathrm{Al}_{2} \mathrm{O}_{3}$ column, $50 \mathrm{~m} \times 530 \mu \mathrm{m} \times 15 \mu \mathrm{m}$ ). The liquid products including $\mathrm{C}_{5}{ }^{+}$non-aromatics and aromatics were analyzed by another Agilent 7890A gas chromatograph equipped with a FID and a capillary column (Agilent 19091S-001, $50 \mathrm{~m} \times 200 \mu \mathrm{m} \times 0.5 \mu \mathrm{m}$ ). The propane conversion and product selectivity were calculated as below:

$$
\begin{gathered}
X_{\text {Propane }}=\frac{\sum C_{i}-C_{\text {propane }}}{\sum C_{i}} \times 100 \% \\
S_{i}=\frac{C_{i}}{\sum C_{i}-C_{\text {propane }}} \times 100 \%
\end{gathered}
$$

where $X_{\text {propane }}(\%)$ is the conversion of propane, $S_{i}(\mathrm{wt} . \%)$ is the selectivity to the target product $i ; C_{i}$ and $C_{\text {propane }}$ (wt.\%) are the corrected mass concentration for species $i$ and propane, respectively.

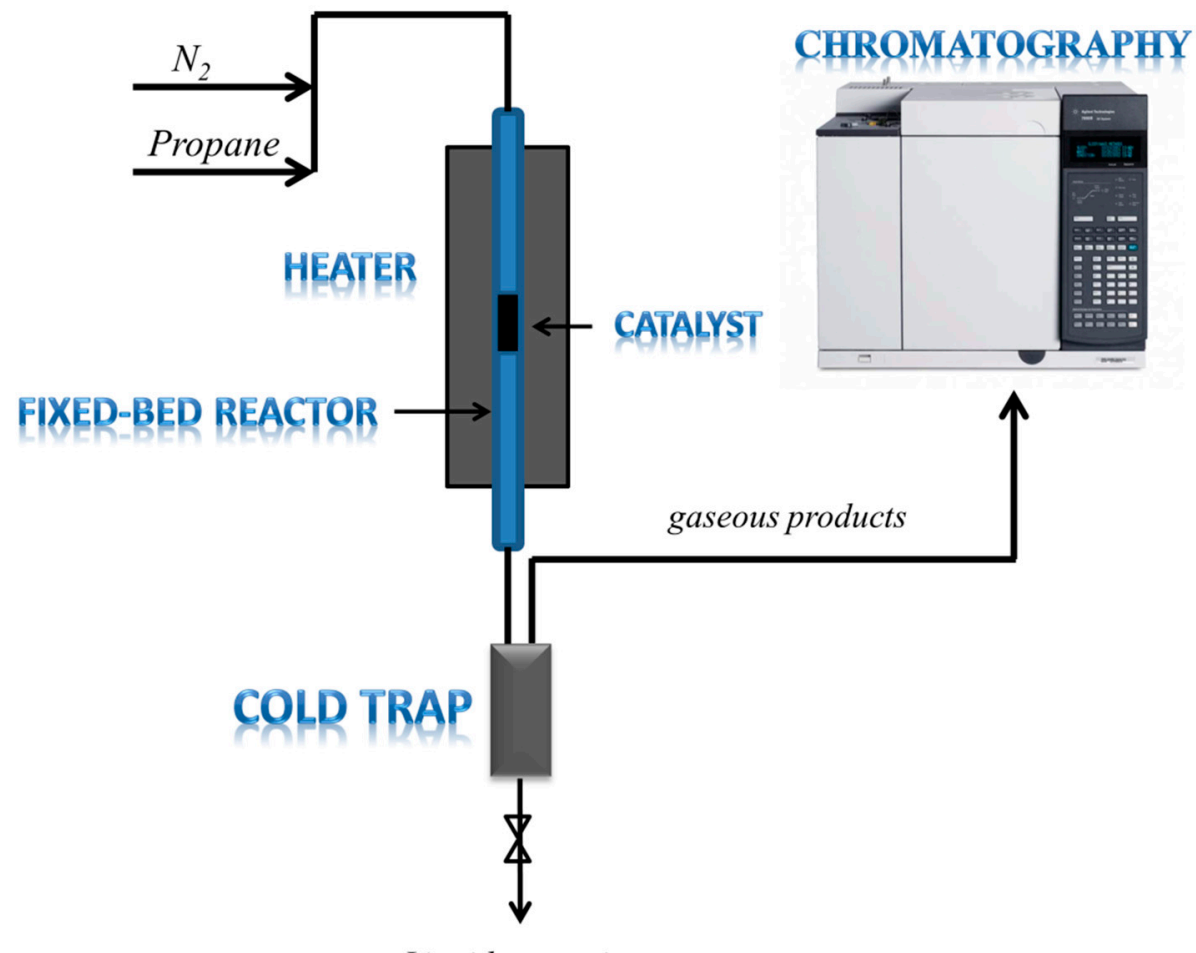

Liquid aromatics

Figure 11. Schematic diagram of fixed-bed reaction process.

\subsubsection{Propane Conversion in a Micro Reactor}

In order to estimate the initial products, conversion of propane was performed in a U-shaped quartz tube micro reactor with an inner diameter of $6 \mathrm{~mm}$. About $100 \mathrm{mg}$ of catalyst (20-40 mesh) 
was loaded in the reactor bed. The reaction was carried out at $500{ }^{\circ} \mathrm{C}$ in a propane/nitrogen flow $(42 \mathrm{~mL} / \mathrm{min})$ as described above. The whole products at a time-on-stream of 2 min were analyzed on-line on a GC as mentioned above. Relative concentration of each product was obtained by dividing the calibrated chromatographic areas of the product by methane concentration since methane results mainly from protolytic cracking of propane on the zeolite protonic sites $[3,40]$.

\subsubsection{Pulse Reaction Test of Propane Conversion}

Pulse reaction test of propane conversion was also conducted in the U-shaped quartz tube reactor as mentioned above. The catalyst was pretreated in a $\mathrm{N}_{2}$ flow $(20 \mathrm{~mL} / \mathrm{min})$ at $500^{\circ} \mathrm{C}$ for $3 \mathrm{~h}$. Then $2.0 \mathrm{~mL}$ propane was injected into the U-shaped quartz tube along with a $\mathrm{N}_{2}$ flow $(20 \mathrm{~mL} / \mathrm{min})$. After $10 \mathrm{~s}$, the carrier gas $\left(\mathrm{N}_{2}\right)$ was switched out. The quartz tube was quenched in liquid nitrogen immediately after $70 \mathrm{~s}$ later of the injection. The retained products in the catalyst were dissolved in $20 \mathrm{wt} . \% \mathrm{HF}$ aqueous solution and subsequently extracted with $\mathrm{CH}_{2} \mathrm{Cl}_{2}$. The extracts, with hexachloroethane as an internal standard (I.S.), were analyzed on a Shimadzu GCMS-QP2010 gas chromatography-mass spectrometry (GC-MS) system equipped with an Rtx-5MS capillary column $(60 \mathrm{~m} \times 0.25 \mathrm{~mm} \times 0.25 \mu \mathrm{m})$.

\subsection{DFT Calculation}

The catalytic kinetic and thermodynamic parameters (details see Table 6) of each reaction step in aromatization process were calculated on the basis of two $120 \mathrm{~T}$ cluster models containing the single $\mathrm{Al}$ and $\mathrm{Al}$ pairs. As shown in Figure 12, for the model of single $\mathrm{Al}$, one $\mathrm{Al}$ atom substituted one $\mathrm{Si}$ atom at $\mathrm{T} 12$ site, whereas two $\mathrm{Al}$ atoms substituted two $\mathrm{Si}$ atoms at $\mathrm{T} 12$ and $\mathrm{T} 7$ sites to form the sequence of $\mathrm{Al}-\mathrm{O}-(\mathrm{Si}-\mathrm{O})_{2}-\mathrm{Al}$ in one ring of zeolite framework. The peripheral silicon atoms were saturated with hydrogen atoms; the distance between hydrogen and silicon atoms ( $\mathrm{Si}-\mathrm{H}$ bond) was $1.47 \AA$, and the direction of which was the same as that of Si-O bond. Density functional theory (DFT) calculations of the catalytic kinetics were performed with the Gaussian 09.D01 package [41]. Details can be found in our former work [26].

a

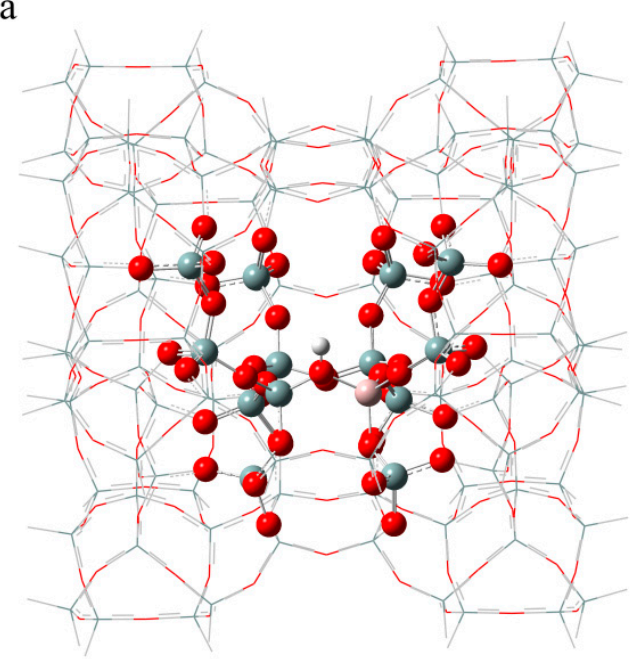

$\mathrm{b}$

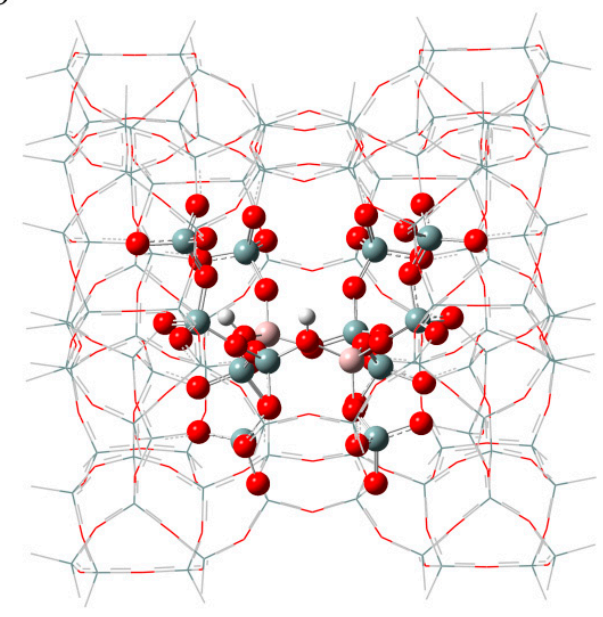

Figure 12. The model of single $\mathrm{Al}$ (a) and $\mathrm{Al}$ pairs (b) of 120T cluster model over H-ZSM-5. Atom coloring: gray $(\mathrm{Si})$, red $(\mathrm{O})$, white $(\mathrm{H})$, and pink $(\mathrm{Al})$.

\section{Conclusions}

Series ZSM- 5 catalysts containing different $\mathrm{Al}_{\mathrm{F}}$ pair contents ( $54.2 \%$ to $64.4 \%$ ) were synthesized by controlling the Na/Al molar ratios (0-1.1) in the precursor gels. The obtained ZSM- 5 catalysts with similar $\mathrm{Si} / \mathrm{Al}_{\mathrm{F}}$ mole ratio, textual properties, morphology, but different $\mathrm{Al}_{\mathrm{F}}$ pairs concentration were applied to propane aromatization reactions. A linear correlation has been established between the 
propane conversion/selectivity of aromatics and $\mathrm{Al}_{\mathrm{F}}$ pairs content. The catalyst $\mathrm{HZ}(0.8)(\mathrm{Na} / \mathrm{Al}$ molar ratio 0.8 in the gel) with the highest paired $\mathrm{Al}_{\mathrm{F}}$ concentration shows the highest propane conversion $(38.2 \%)$ and aromatics selectivity (19.7 wt.\%), which is about 1.5 times (for conversion) and almost 2.5 times (for aromatics selectivity) higher than that of $\mathrm{HZ}(0)$ catalyst. Propane pulse experiment, micro reactor activity estimation, Operando diffuse reflectance ultraviolet-visible (DR UV-vis) spectra and FTIR characterization of coke species on the used catalysts suggest that the present of more $\mathrm{Al}_{\mathrm{F}}$ pairs in the ZSM-5 framework promotes the oligomerization and cyclization reactions of olefins and leads to the production of more aromatics. DFT calculation results indicate that the HZSM- 5 zeolite containing $\mathrm{Al}_{\mathrm{F}}$ pairs shows lower free energy barrier and higher rate constants for cyclization and hydride transfer reactions than the HZSM- 5 zeolite containing single $\mathrm{Al}_{\mathrm{F}}$; the structure of $\mathrm{Al}_{\mathrm{F}}$ pairs in the HZSM-5 zeolite exhibits stronger electrostatic stabilization effect on the transition states than that of single $\mathrm{Al}_{\mathrm{F}}$. This study provided a theoretical guidance to design catalysts for propane aromatization.

Author Contributions: H.W., H.Z. and W.F. conceived and designed the experiments; D.S. carried out most of the experiments and characterizations; S.W. performed all the DFT calculations; D.S. and S.W. co-wrote the manuscript; P.W., L.Z., Z.Q. and J.W. discussed the results and gave many valuable suggestions for improving the work. All authors have read and agreed to the published version of the manuscript.

Funding: This work was financially supported by the National Natural Science Foundation of China (21773281, 21991092, U1910203, 21802157, U1862101 and 21875275), Natural Science Foundation of Shanxi Province of China (201901D211581 and 201801D221092).

Acknowledgments: The calculations are performed on the Computer Network Information Center of Chinese Academy of Sciences.

Conflicts of Interest: The authors declare no conflict of interest.

\section{References}

1. Bhan, A.; Delgass, W.N. Propane Aromatization over HZSM-5 and Ga/HZSM-5 Catalysts. Catal. Rev. 2008, 50, 19-151. [CrossRef]

2. Zhang, P.; Tan, L.; Yang, G.; Tsubaki, N. One-pass selective conversion of syngas to paraxylene. Chem. Sci. 2017, 8, 7941-7946. [CrossRef] [PubMed]

3. Guisnet, M.; Gnep, N.S.; Alario, F. Aromatization of short chain alkanes on zeolite catalysts. Appl. Catal. A Gen. 1992, 89, 1-30. [CrossRef]

4. Al-Yassir, N.; Akhtar, M.N.; Al-Khattaf, S. Physicochemical properties and catalytic performance of galloaluminosilicate in aromatization of lower alkanes: A comparative study with Ga/HZSM-5. J. Porous Mater. 2012, 19, 943-960. [CrossRef]

5. Su, X.; Wang, G.; Bai, X.; Wu, W.; Xiao, L.; Fang, Y.; Zhang, J. synthesis of nanosized HZSM-5 zeolites isomorphously substituted by gallium and their catalytic performance in the aromatization. Chem. Eng. J. 2016, 293, 365-375. [CrossRef]

6. Choudhary, V.R.; Sivadinarayana, C.; Kinage, A.K.; Devadas, P.; Guisnet, M. H-Gallosilicate (MFI) propane aromatization catalyst Influence of calcination temperature on acidity, activity and deactivation due to coking. Appl. Catal. A Gen. 1996, 136, 125-142. [CrossRef]

7. Montes, A.; Giannetto, G. A new way to obtain acid or bifunctional catalysts: V. Considerations on bifunctionality of the propane aromatization reaction over [Ga,Al]-ZSM-5 catalysts. Appl. Catal. A Gen. 2000, 197, 31-39. [CrossRef]

8. Rodrigues, V.O.; Faro Júnior, A.C. On catalyst activation and reaction mechanisms in propane aromatization on Ga/HZSM5 catalysts. Appl. Catal. A Gen. 2012, 435, 68-77. [CrossRef]

9. Choudhary, V.R.; Kinage, A.K.; Sivadinarayana, C.; Devadas, P.; Sansare, S.D.; Guisnet, M. H-Gallosilicate (MFI) Propane Aromatization Catalyst: Influence of Si/Ga Ratio on Acidity, Activity and Deactivation Due to Coking. J. Catal. 1996, 158, 34-50. [CrossRef]

10. Han, J.; Jiang, G.; Han, S.; Liu, J.; Zhang, Y.; Liu, Y.; Wang, R.; Zhao, Z.; Xu, C.; Wang, Y.; et al. The Fabrication of $\mathrm{Ga}_{2} \mathrm{O}_{3} / \mathrm{ZSM}-5$ Hollow Fibers for Efficient Catalytic Conversion of n-Butane into Light Olefins and Aromatics. Catalysts 2016, 6, 13. [CrossRef] 
11. Al-Yassir, N.; Akhtar, M.N.; Ogunronbi, K.; Al-Khattaf, S. Synthesis of stable H-galloaluminosilicate MFI with hierarchical pore architecture by surfactant-mediated base hydrolysis, and their application in propane aromatization. J. Mol. Catal. A Chem. 2012, 360, 1-15. [CrossRef]

12. Guisnet, M.; Gnep, N.S.; Aittaleb, D.; Doyemet, Y.J. Conversion of light alkanes into aromatic hydrocarbons: VI. Aromatization of C2-C4 alkanes on H-ZSM-5-Reaction mechanisms. Appl. Catal. A Gen. 1992, 87, 255-270. [CrossRef]

13. Biscardi, J.A.; Iglesia, E. Isotopic Tracer Studies of Propane Reactions on H- ZSM5 Zeolite. J. Phys. Chem. B 1998, 102, 9284-9289. [CrossRef]

14. Meriaudeau, P.; Naccache, C. Further Evidence on the Change of Acid Properties of H-ZSM-5 by Ga and Pt. J. Catal. 1995, 157, 283-288. [CrossRef]

15. Biscardi, J.A.; Meitzner, G.D.; Iglesia, E. Structure and Density of Active Zn Species in Zn/H-ZSM5 Propane Aromatization Catalysts. J. Catal. 1998, 179, 192-202. [CrossRef]

16. Dedecek, J.; Kaucky, D.; Wichterlova, B.; Gonsiorova, O. $\mathrm{Co}^{2+}$ ions as probes of $\mathrm{Al}$ distribution in the framework of zeolites. ZSM-5 study. Phys. Chem. Chem. Phys. 2002, 4, 5406-5413. [CrossRef]

17. Liang, T.; Chen, J.; Qin, Z.; Li, J.; Wang, P.; Wang, S.; Wang, G.; Dong, M.; Fan, W.; Wang, J. Conversion of Methanol to Olefins over H-ZSM-5 Zeolite: Reaction Pathway Is Related to the Framework Aluminum Siting. ACS Catal. 2016, 6, 7311-7325. [CrossRef]

18. Wang, S.; Wang, P.; Qin, Z.; Chen, Y.; Dong, M.; Li, J.; Zhang, K.; Liu, P.; Wang, J.; Fan, W. Relation of Catalytic Performance to the Aluminum Siting of Acidic Zeolites in the Conversion of Methanol to Olefins, Viewed via a Comparison between ZSM-5 and ZSM-11. ACS Catal. 2018, 8, 5485-5505. [CrossRef]

19. Biligetu, T.; Wang, Y.; Nishitob, T.; Otomo, R.; Park, S.; Mochizuki, H.; Kondo, J.N.; Tatsumi, T.; Yokoi, T. $\mathrm{Al}$ distribution and catalytic performance of ZSM-5 zeolites synthesized with various alcohols. J. Catal. 2017, 353, 1-10. [CrossRef]

20. Sazama, P.; Dedecek, J.; Gábová, V.; Wichterlová, B.; Spoto, G.; Bordiga, S. Effect of aluminium distribution in the framework of ZSM-5 on hydrocarbon transformation. Cracking of 1-butene. J. Catal. 2008, 254, 180-189. [CrossRef]

21. Yokoi, T.; Mochizuki, H.; Namba, S.; Kondo, J.N.; Tatsumi, T. Control of the Al distribution in the framework of ZSM-5 zeolite and its evaluation by solid-state NMR technique and catalytic properties. J. Phys. Chem. C 2015, 119, 15303-15315. [CrossRef]

22. Bjorgen, M.; Svelle, S.; Joensen, F.; Nerlov, J.; Kolboe, S.; Bonino, F.; Palumbo, L.; Bordiga, S.; Olsbye, U. Conversion of methanol to hydrocarbons over zeolite H-ZSM-5: On the origin of the olefinic species. J. Catal. 2007, 249, 195-207. [CrossRef]

23. Song, C.; Chu, Y.; Wang, M.; Shi, H.; Zhao, L.; Guo, X.; Yang, W.; Shen, J.; Xue, N.; Peng, L.; et al. Cooperativity of adjacent Brønsted acid sites in MFI zeolite channel leads to enhanced polarization and cracking of alkanes. J. Catal. 2017, 349, 163-174. [CrossRef]

24. Tabor, E.; Bernauer, M.; Wichterlová, B.; Dedecek, J. Enhancement of propene oligomerization and aromatization by proximate protons in zeolites; FTIR study of the reaction pathway in ZSM-5. Catal. Sci. Technol. 2019, 9, 4262-4275. [CrossRef]

25. Li, J.; Ma, H.; Chen, Y.; Xu, Z.; Li, C.; Ying, W. Conversion of methanol to propylene over hierarchical HZSM-5: The effect of Al spatial distribution. Chem. Commun. 2018, 54, 6032-6035. [CrossRef]

26. Wang, S.; Li, S.; Zhang, L.; Qin, Z.; Dong, M.; Li, J.; Wang, J.; Fan, W. Insight into the effect of incorporation of boron into ZSM-11 on its catalytic performance for conversion of methanol to olefins. Catal. Sci. Technol. 2017, 7, 4766-4779. [CrossRef]

27. Dai, W.; Wu, G.; Li, L.; Guan, N.; Hunger, M. Mechanisms of the Deactivation of SAPO-34 Materials with Different Crystal Sizes Applied as MTO Catalysts. ACS Catal. 2013, 3, 588-596. [CrossRef]

28. Bjørgen, M.; Bonino, F.; Kolboe, S.; Lillerud, K.-P.; Zecchina, A.; Bordiga, S. Spectroscopic Evidence for a Persistent Benzenium Cation in Zeolite H-Beta. J. Am. Chem. Soc. 2003, 125, 15863-15868. [CrossRef]

29. Wulfers, M.J.; Jentoft, F.C. Identification of carbonaceous deposits formed on H-mordenite during alkane isomerization. J. Catal. 2013, 307, 204-213. [CrossRef]

30. Borodina, E.; Sharbini Harun Kamaluddin, H.; Meirer, F.; Mokhtar, M.; Asiri, A.M.; Al Thabaiti, S.A.; Basahel, S.N.; Ruiz-Martinez, J.; Weckhuysen, B.M. Influence of the Reaction Temperature on the Nature of the Active and Deactivating Species during Methanol-to-Olefins Conversion over H-SAPO-34. ACS Catal. 2017, 7, 5268-5281. [CrossRef] 
31. Borodina, E.; Meirer, F.; Lezcano-Gonzalez, I.; Mokhtar, M.; Asiri, A.M.; Al-Thabaiti, S.A.; Basahel, S.N.; Ruiz-Martinez, J.; Weckhuysen, B.M. Influence of the Reaction Temperature on the Nature of the Active and Deactivating Species during Methanol to Olefins Conversion over H-SSZ-13. ACS Catal. 2015, 5, 992-1003. [CrossRef]

32. Xue, Y.; Li, J.; Wang, S.; Cui, X.; Dong, M.; Wang, G.; Qin, Z.; Wang, J.; Fan, W. Co-reaction of methanol with butene over a high-silica H-ZSM-5 catalyst. J. Catal. 2018, 367, 315-325. [CrossRef]

33. Song, C.; Liu, K.; Zhang, D.; Liu, S.; Li, X.; Xie, S.; Xu, L. Effect of cofeeding n-butane with methanol on aromatization performance and coke formation over a Zn loaded ZSM-5/ZSM-11 zeolite. Appl. Catal. A Gen. 2014, 470, 15-23. [CrossRef]

34. Hernandez, E.D.; Jentoft, F.C. Spectroscopic Signatures Reveal Cyclopentenyl Cation Contributions in Methanol-to-Olefins Catalysis. ACS Catal. 2020, 10, 5764-5782. [CrossRef]

35. Emdadi, L.; Mahoney, L.; Lee, I.C.; Leff, A.C.; Wu, W.; Liu, D.; Nguyen, C.K.; Tran, D.T. Assessment of coke deposits on lamellar metal-modifed MFI zeolites in ethylene transformation to aromatic liquids. Appl. Catal. A Gen. 2020, 595, 117510-117520. [CrossRef]

36. Maksoud, W.A.; Gevers, L.E.; Vittenet, J.; Ould-Chikh, S.; Telalovic, S.; Bhatte, K.; Abou-Hamad, E.; Anjum, D.H.; Hedhili, M.N.; Vishwanath, V.; et al. A strategy to convert propane to aromatics (BTX) using TiNp 4 grafted at the periphery of ZSM-5 by surface organometallic chemistry. Dalton Trans. 2019, 48, 6611-6620. [CrossRef]

37. Wang, C.; Wang, Y.; Du, Y.; Yang, G.; Xie, Z. Similarities and differences between aromatic-based and olefin-based cycles in H-SAPO-34 and H-SSZ-13 for methanol-to-olefins conversion: Insights from energetic span model. Catal. Sci. Technol. 2015, 5, 4354-4364. [CrossRef]

38. Wang, S.; Chen, Y.; Wei, Z.; Qin, Z.; Ma, H.; Dong, M.; Li, J.; Fan, W.; Wang, J. Polymethylbenzene or alkene cycle? theoretical study on their contribution to the process of methanol to olefins over H-ZSM-5 zeolite. J. Phys. Chem. C 2015, 119, 28482-28498. [CrossRef]

39. Wang, S.; Chen, Y.; Qin, Z.; Zhao, T.; Fan, S.; Dong, M.; Li, J.; Fan, W.; Wang, J. Origin and evolution of the initial hydrocarbon pool intermediates in the transition period for the conversion of methanol to olefins over H-ZSM-5 zeolite. J. Catal. 2019, 369, 382-395. [CrossRef]

40. Guisnet, M.; Gnep, N.S. Aromatization of propane over GaHMFI catalysts. Reaction scheme, nature of the dehydrogenating species and mode of coke formation. Catal. Today 1996, 31, 275-292. [CrossRef]

41. Frisch, M.J.; Trucks, G.W.; Schlegel, H.B.; Scuseria, G.E.; Robb, M.A.; Cheeseman, J.R.; Scalmani, G.; Barone, V.; Mennucci, B.; Petersson, G.A.; et al. Gaussian 09, Revision D.01; Gaussian, Inc.: Wallingford, CT, USA, 2009. 